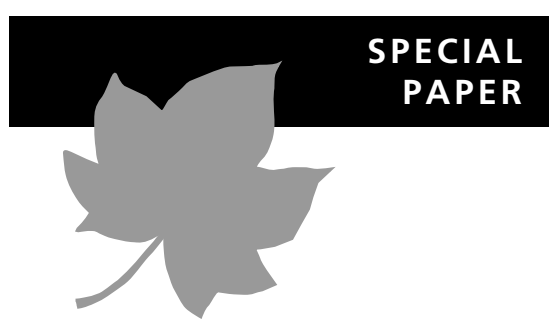

\title{
Atlantic reef fish biogeography and evolution
}

S. R. Floeter ${ }^{1,2 \star}$, L. A. Rocha ${ }^{3}$, D. R. Robertson ${ }^{4}$, J. C. Joyeux ${ }^{5}$, W. F. SmithVaniz $^{6}$, P. Wirtz ${ }^{7}$, A. J. Edwards ${ }^{8}$, J. P. Barreiros ${ }^{9}$, C. E. L. Ferreira ${ }^{10}$, J. L. Gasparini ${ }^{5}$, A. Brito ${ }^{11}$, J. M. Falcón ${ }^{11}$, B. W. Bowen ${ }^{3}$ and G. Bernardi ${ }^{12}$

${ }^{1}$ National Center for Ecological Analysis and Synthesis, University of California, 735 State St., 300, Santa Barbara, CA, 93101, USA, ${ }^{2}$ Departamento de Ecologia e Zoologia, Lab. de Biogeografia e Macroecologia Marinha, Universidade Federal de Santa Catarina, Florianópolis, SC 88010-970, Brazil, ${ }^{3}$ Hawaii Institute of Marine Biology, University of Hawaii, Kaneohe, HI, 96744, USA, ${ }^{4}$ Smithsonian Tropical Research Institute, Balboa, Unit 0948, APO AA 34002, Panama, ${ }^{5}$ Departamento de Ecologia e Recursos Naturais, Universidade Federal do Espírito Santo, Vitória, ES, 29060-900, Brazil, ${ }^{6} U S$ Geological Survey, Florida Integrated Science Center, Gainesville, FL, 32653, USA, ${ }^{7}$ Centro de Ciências do Mar, Universidade do Algarve, Faro, P-8000-117, Portugal, ${ }^{8}$ School of Biology, Newcastle University, Newcastle upon Tyne, NE1 7RU, UK, ${ }^{9}$ Departamento de Ciências Agrárias, Universidade dos Açores, 9701-851, Portugal, ${ }^{10}$ Departamento de Biologia Marinha, Universidade Federal Fluminense, Niterói, RJ, 24001-970, Brazil, ${ }^{11}$ Dpto. Biología Animal (Ciencias Marinas), Universidad de La Laguna, La Laguna, Tenerife, Islas Canarias, 38206, Spain, ${ }^{12}$ Department of Ecology and Evolutionary Biology, University of California, Santa Cruz, CA, 95060, USA

${ }^{\star}$ Correspondence: S. R. Floeter, Departamento de Ecologia e Zoologia, Lab. de Biogeografia e Macroecologia Marinha, Universidade Federal de Santa Catarina, Florianópolis, SC 88010-970, Brazil.

E-mail: floeter@ccb.ufsc.br

\section{ABSTRACT}

Aim To understand why and when areas of endemism (provinces) of the tropical Atlantic Ocean were formed, how they relate to each other, and what processes have contributed to faunal enrichment.

Location Atlantic Ocean.

Methods The distributions of 2605 species of reef fishes were compiled for 25 areas of the Atlantic and southern Africa. Maximum-parsimony and distance analyses were employed to investigate biogeographical relationships among those areas. A collection of 26 phylogenies of various Atlantic reef fish taxa was used to assess patterns of origin and diversification relative to evolutionary scenarios based on spatio-temporal sequences of species splitting produced by geological and palaeoceanographic events. We present data on faunal (species and genera) richness, endemism patterns, diversity buildup (i.e. speciation processes), and evaluate the operation of the main biogeographical barriers and/or filters.

Results Phylogenetic (proportion of sister species) and distributional (number of shared species) patterns are generally concordant with recognized biogeographical provinces in the Atlantic. The highly uneven distribution of species in certain genera appears to be related to their origin, with highest species richness in areas with the greatest phylogenetic depth. Diversity buildup in Atlantic reef fishes involved (1) diversification within each province, (2) isolation as a result of biogeographical barriers, and (3) stochastic accretion by means of dispersal between provinces. The timing of divergence events is not concordant among taxonomic groups. The three soft (non-terrestrial) inter-regional barriers (mid-Atlantic, Amazon, and Benguela) clearly act as 'filters' by restricting dispersal but at the same time allowing occasional crossings that apparently lead to the establishment of new populations and species. Fluctuations in the effectiveness of the filters, combined with ecological differences among provinces, apparently provide a mechanism for much of the recent diversification of reef fishes in the Atlantic.

Main conclusions Our data set indicates that both historical events (e.g. Tethys closure) and relatively recent dispersal (with or without further speciation) have had a strong influence on Atlantic tropical marine biodiversity and have contributed to the biogeographical patterns we observe today; however, examples of the latter process outnumber those of the former.

\section{Keywords}

Atlantic Ocean, biodiversity, biogeographical barriers, biogeographical provinces, historical biogeography, marine biogeography, phylogeography, speciation, Tethys Sea. 
'To some scholars, the search for patterns is a fishing expedition, an unworthy exercise... To me, however, it provides the critical raw data that enable us to propose and to constrain possible explanations. Patterns help us to identify... critical circumstances of events that could affect diversity'. (Vermeij, 1996).

\section{INTRODUCTION}

Marine biogeographers have used the geography of endemism to divide the biosphere into major provinces/regions (Ekman, 1953; Briggs, 1974; Vermeij, 1978), each of which is characterized by a number of species found only in limited geographical areas, known as areas of endemism. For simplicity we will use the term 'province' to identify major areas of endemism (Briggs, 1974, 1995). In characterizing biogeographical provinces, it is necessary to recognize the types of barriers or boundaries that separate them (Briggs, 1973, 1974; Floeter \& Gasparini, 2000; Joyeux et al., 2001; Rocha, 2003). It is also a general aim to understand why and when these provinces were formed, and how they relate to each other (Vermeij, 2001). In order to achieve these goals we need to learn more about richness and endemism patterns, diversity buildup (i.e. speciation processes), ecological and palaeoecological settings, and the operation of biogeographical barriers or filters.

Here we discuss the geographic distribution and evolution of Atlantic 'reef fishes', a group that includes any shallow $(<100 \mathrm{~m})$ tropical/subtropical benthic or benthopelagic fishes that consistently associate with hard substrates of coral, algal, or rocky 'reefs' or occupy adjacent sand substrate. The distribution of the great majority of reef fishes is dependent on the dispersal of eggs and larvae in ocean currents, since these fishes are relatively sedentary during adult stages (Leis, 1991; Victor, 1991). Reef fishes are highly diverse; they are not limited to tropical reef areas (like reef-building corals) and thus are ideal for comparisons involving centres of high diversity and peripheral, lower-diversity areas; they are relatively easy to identify compared with other groups (e.g. sponges, ascidians); and, finally, a number of reef fish phylogenies (mainly molecular) have been published in the last decade, providing insights into speciation patterns within a geographic context.

The tropical Atlantic reef fauna encompasses four primary provinces: Brazil, the 'Greater' Caribbean, the Mid-Atlantic Ridge, and the Eastern Atlantic (Table 1; Briggs, 1974). Five major barriers define these regions. The first is the $>3500-\mathrm{km}$ wide Atlantic itself, which gradually began to form as a deep ocean barrier (the mid-Atlantic Barrier, MAB) following the separation of Africa and South America c. 84 Ma (Pittman et al., 1993). The second barrier emerged c. 12-18 Ma with the uplift of the Red Sea land bridge, separating the tropical faunas of the Atlantic from the Indian Ocean and closing the Tethys Seaway in the Terminal Tethyan Event (TTE; Steininger \& Rögl, 1984; Bellwood \& Wainwright, 2002). The third barrier is the freshwater outflow from the Orinoco and Amazon rivers, which spans $2300 \mathrm{~km}$ of the NE coast of South America, separating
Brazilian and Caribbean reef habitats, and which was established c. $11 \mathrm{Ma}$ (Hoorn et al., 1995). The final closure of the Isthmus of Panama (IOP) c. 3.1 Ma (Coates \& Obando, 1996) separated the Caribbean from the Tropical Eastern Pacific. Finally, the tropical reef fauna of the Atlantic has been isolated from the southern Indian Ocean by the cold Benguela Current for at least $2 \mathrm{Myr}$ (the Benguela barrier; Shannon, 1985; Marlow et al., 2000). These geographic and oceanographic features are regarded as the primary barriers or filters producing divergences and speciation among the regional faunas of the Atlantic.

The Atlantic provinces proposed by Briggs (1974) were based on fewer (and less reliable) species distributional data, and he did not have access to modern statistical methods. Here we assemble the first comprehensive distribution data base for the entire tropical and subtropical Atlantic, including the southwestern Indian Ocean. Recent field and taxonomic research in understudied areas, such as tropical West Africa (e.g. Afonso et al., 1999; Edwards et al., 2003; Wirtz et al., 2007), the Brazilian coast (e.g. Floeter et al., 2001; Rocha \& Rosa, 2001; Menezes et al., 2003; Dutra et al., 2005), and associated oceanic islands (e.g. Santos et al., 1997; Gasparini \& Floeter, 2001; Feitoza et al., 2003), revealed new species (e.g. Sazima et al., 1998; Rocha \& Rosa, 1999; Heiser et al., 2000; Gasparini et al., 2003), and greatly advanced the knowledge of geographical distributions of tropical reef fishes. Concurrently, new data were made available on the palaeoceanographic characteristics of the tropical Atlantic (e.g. Stramma \& Schott, 1999; Marlow et al., 2000; Peeters et al., 2004). Many morphological and molecular phylogenies of Atlantic reef fishes (see Methods) have recently been published and can help to elucidate historical affinities among endemism areas, as well as the origins and diversification patterns of Atlantic reef fishes.

This paper has a number of purposes, namely: (1) to summarize current information on diversity and endemism in Atlantic reef fishes; (2) to evaluate relationships among the main Atlantic biogeographical regions, analysing the effect of the various barriers or filters on these relationships; and (3) to review published phylogenies (mainly derived from recent molecular studies) and assess origins and diversification patterns of Atlantic reef fishes by addressing the following questions: (a) what is the geographical pattern of sister taxa among provinces? (b) are area relationships based on phylogenetic and distributional patterns concordant? (c) is there a congruent pattern of divergences resulting from historical events? (d) what is the relative importance of vicariant events and dispersal across soft barriers on contemporary biodiversity?

\section{METHODS}

\section{Atlantic reef fish data base}

Species lists were compiled for 25 areas of the Atlantic Ocean through literature searches of peer-reviewed checklists and published field guides, and from extensive observations by the authors (see Table 1 for area definition and references used). This data base represents the most exhaustive data set on the 
S. R. Floeter et al.

Table 1 Definitions of the studied areas of the Atlantic Ocean and references of checklists used to compile the data set. Regions were based on the results of the maximum-parsimony analysis. Entries in italics signify two or more areas pertaining to the same geographic group.

\begin{tabular}{|c|c|c|c|}
\hline Province & Area & Geographical definition & References \\
\hline \multicolumn{4}{|c|}{ Northwestern Atlantic (NWA) } \\
\hline Carolinian & Carolinian & $\begin{array}{l}\text { From Cape Kennedy to } \\
\text { North Carolina }\end{array}$ & $\begin{array}{l}\text { Smith-Vaniz et al. (1999), } \\
\text { Quattrini et al. (2004) }\end{array}$ \\
\hline \multirow[t]{3}{*}{ Greater Caribbean } & Bermuda & & Smith-Vaniz et al. (1999) \\
\hline & Western Caribbean & $\begin{array}{l}\text { Continental area from } \\
\text { Florida to Tobago and } \\
\text { Venezuela (including } \\
\text { Gulf of Mexico) }\end{array}$ & $\begin{array}{l}\text { Cervigón (1982), Smith-Vaniz et al. (1999), } \\
\text { Smith (1997), Randall (1996), } \\
\text { Schmitter-Soto et al. (2000), } \\
\text { Smith et al. }(2002,2003)\end{array}$ \\
\hline & Eastern Caribbean & $\begin{array}{l}\text { Insular area from } \\
\text { Bahamas, Cuba to } \\
\text { Dominica and Barbados }\end{array}$ & $\begin{array}{l}\text { Böhlke \& Chaplin (1993), } \\
\text { Smith-Vaniz et al. (1999), } \\
\text { Claro \& Parenti (2001), } \\
\text { Smith et al. (2002), } \\
\text { Smith-Vaniz et al. (2006) }\end{array}$ \\
\hline
\end{tabular}

Southwestern Atlantic (SWA) Brazilian
Northeastern Brazil

From the Mouth of the Amazon to southern Bahia

Southeastern Brazil

Atol das Rocas

Fernando de Noronha

St Paul's Rocks

Trindade Is.
Carvalho-Filho (1999), Rocha et al. (1998), Feitoza (2001), Rocha \& Rosa (2001), Menezes et al. (2003), Feitoza et al. (2005), Dutra et al. (2005), S.R. Rosa, C.R.R. Nunes \& L.A. Rocha (unpublished manuscript)

Menezes et al. (2003), Floeter et al. (2007), Hostim-Silva et al. (2006)

Rosa \& Moura (1997), Menezes et al. (2003), Sampaio et al. (2006)

Menezes et al. (2003), Sampaio et al. (2006)

Lubbock \& Edwards (1981),

Feitoza et al. (2003), Sampaio et al. (2006)

Gasparini \& Floeter (2001), Menezes et al. (2003), Sampaio et al. (2006)

\begin{tabular}{|c|c|c|c|}
\hline Eastern South America & 'Argentina' & $\begin{array}{l}\text { From Uruguay to } \\
\text { Patagonia }\end{array}$ & $\begin{array}{l}\text { Menni et al. }(1984) \\
\text { Cousseau \& Perrota (2004) }\end{array}$ \\
\hline \multirow[t]{2}{*}{ Mid-Atlantic Ridge (MAR) } & Ascension & & $\begin{array}{l}\text { Lubbock (1980), D.R. Robertson } \\
\text { (personal observation) }\end{array}$ \\
\hline & St Helena & & $\begin{array}{l}\text { Edwards \& Glass (1987a,b), Edwards (1990), } \\
\text { D.R. Robertson (personal observation) }\end{array}$ \\
\hline \multirow[t]{5}{*}{ Northeastern Atlantic (NEA) } & Western Mediterranean & $\begin{array}{l}\text { Gibraltar to the Strait } \\
\text { of Messina }\end{array}$ & Jennings (2000), Hureau (1998) \\
\hline & Eastern Mediterranean & $\begin{array}{l}\text { Levant to the Strait } \\
\text { of Messina }\end{array}$ & Jennings (2000), Hureau (1998) \\
\hline & Azores & Macaronesia & Santos et al. (1997) \\
\hline & Madeira & Macaronesia & $\begin{array}{l}\text { Quéro et al. (1990), Wirtz (2001), } \\
\text { Wirtz (unpublished data) }\end{array}$ \\
\hline & Canaries & Macaronesia & Brito et al. (2002) \\
\hline \multirow[t]{4}{*}{ Tropical Eastern Atlantic (TEA) } & Northwest Africa & $\begin{array}{l}\text { Gibraltar to Cape } \\
\text { Verde (Senegal) }\end{array}$ & $\begin{array}{l}\text { Quéro et al. (1990), Almada et al. (2001), } \\
\text { Falcón et al. (2002) }\end{array}$ \\
\hline & Cape Verde Is. & & $\begin{array}{l}\text { Reiner (1996), Brito et al. (1999), } \\
\text { Menezes et al. (2004) }\end{array}$ \\
\hline & São Tomé \& Príncipe & Includes Annobon & Afonso et al. (1999), Wirtz et al. (2007) \\
\hline & Tropical West Africa & $\begin{array}{l}\text { Cape Verde to } \\
\text { Moçamedes (Angola) }\end{array}$ & $\begin{array}{l}\text { Quéro et al. (1990), Reiner (2001), } \\
\text { Edwards et al. (2003) }\end{array}$ \\
\hline
\end{tabular}


Table 1

continued.

\begin{tabular}{|c|c|c|c|}
\hline Province & Area & Geographical definition & References \\
\hline \multirow[t]{2}{*}{ Southwest Africa (SA) } & Benguela & $\begin{array}{l}\text { From Moçamedes } \\
\text { (Angola) to the } \\
\text { Cape of Good Hope }\end{array}$ & $\begin{array}{l}\text { Smith \& Heemstra (1995), Heemstra \& } \\
\text { Heemstra (2004), L.E. Beckley, P.A. Hulley, \& } \\
\text { P.H. Skelton (unpublished manuscript), } \\
\text { D. Polack (personal communication) }\end{array}$ \\
\hline & Agulhas & $\begin{array}{l}\text { From the Cape of } \\
\text { Good Hope to } \\
\text { Kei River }\end{array}$ & $\begin{array}{l}\text { Smith \& Heemstra (1995), } \\
\text { Heemstra \& Heemstra (2004), L.E. Beckley, } \\
\text { P.A. Hulley, \& P.H. Skelton } \\
\text { (unpublished manuscript), } \\
\text { D. Polack (personal communication) }\end{array}$ \\
\hline $\begin{array}{l}\text { Southwestern Indian } \\
\text { Ocean (SWIO) }\end{array}$ & $\begin{array}{l}\text { South Africa's } \\
\text { Indian Ocean }\end{array}$ & $\begin{array}{l}\text { From Kei River to } \\
\text { Kosi Bay }\end{array}$ & $\begin{array}{l}\text { Smith \& Heemstra (1995), } \\
\text { Heemstra \& Heemstra (2004), L.E. Beckley, } \\
\text { P.A. Hulley \& P.H. Skelton } \\
\text { (unpublished manuscript), } \\
\text { D. Polack (personal communication) }\end{array}$ \\
\hline
\end{tabular}

distributions of Atlantic reef fishes compiled to date (Table S1, Supplementary Material).

\section{Atlantic reef fish phylogenies}

The following phylogenies were used for analysis and inferences: Abudefduf (Quenouille et al., 2004), Acanthostracion/ Lactophrys (Klassen, 1995), Acanthurus (Rocha et al., 2002), Alphestes (Craig et al., 2004, 2006), Anisotremus (Bernardi \& Lape, 2005), Aulostomus (Bowen et al., 2001), Centropyge 'xiphipops' complex (Bowen et al., 2006a), chaenopsids (Hastings, 2000), Chromis (Quenouille et al., 2004; C. chromis clade - Domingues et al., 2005; C. 'multilineata' complex - L.A. Rocha, D.R. Robertson, A.J. Edwards \& B.W. Bowen, in preparation), Clepticus (Heiser et al., 2000), Dermatolepis (Craig et al., 2004), Diplodus (Summerer et al., 2001), Elacatinus (Taylor \& Hellberg, 2005), Gnatholepis (Rocha et al., 2005a), Gobiesocinae (Briggs, 1955), Hippocampus (Casey et al., 2004), Halichoeres (Rocha, 2004; Barber \& Bellwood, 2005), Holacanthus (Bellwood et al., 2004; G. Bernardi, S.R. Floeter \& D.R. Robertson, in preparation), Lethrinus (Galbo et al., 2002), Ophioblennius (Muss et al., 2001), Pomacanthus (Bellwood et al., 2004), Rypticus (Guimarães, 1999; Carlin et al., 2003), Sparisoma/Nicholsina (Robertson et al., 2006), Sparidae (Orrell et al., 2002), Strongylura (Banford et al., 2004), and Thalassoma (Costagliola et al., 2004).

When interpreting the phylogenies we assumed that no extinctions have occurred, and followed estimates (and associated errors) of the timing of speciation events provided and discussed in the original publications. A minimum age of 3.1 Ma was assumed for splits related to the closure of the Isthmus of Panama.

\section{Data analyses}

Maximum-parsimony (MP) analyses of 25 geographical areas in the Atlantic Ocean were performed using PAUP ${ }^{\star}$ (Swofford,
2002). Geographical areas were characterized by the presence/ absence of 2605 reef fish taxa. MP analyses were performed with heuristic searches having starting trees obtained by means of the tree-bisection-reconnection (TBR) branch-swapping algorithm. Support for each node from the majority consensus tree from the data set was investigated with 1000 bootstrap pseudo-replicates (Felsenstein, 2004).

To evaluate relationships among areas based on reef fish phylogenies, we calculated the ratio (proportion; given in each arrow) between the number of nodes in which two areas form a sister pair in a given phylogeny (when the terminal clade was a polytomy, the relationships were counted for all the areas involved, i.e. overlap) and the number of times the same pairs of areas were available for evaluation in the studied phylogenies. The number of studied pairs (possibilities of interactions) was around 300 for the seven areas in the studied phylogenies. It is important to note that not all phylogenies include taxa present in all the areas, and some have more than one pair of sister areas; we thus worked with proportions of the areas in question (to avoid bias related to unequal coverage of areas).

In order to summarize the relationships among the areas, cluster analyses (Bray-Curtis dissimilarity index and UPGMA method) were performed using Mvsp software based on: (1) the number of reef fish species (or genera) common to the pairs of areas, and (2) the matrix of ratios indicating the importance of the phylogenetic connections. Varying the clustering routine had no effect on the grouping of the sites, except when indicated in the figure legend.

\section{RESULTS AND DISCUSSION}

\section{Geographical distributions}

\section{Diversity and endemism}

In total, our data base covers 1720 teleost reef fish species from 465 genera and 69 families from the Atlantic, plus another 885 
Table 2 Species richness, number of endemics and endemism (\%) of Atlantic areas and South Africa's Indian Ocean*.

\begin{tabular}{|c|c|c|c|}
\hline & Richness & Endemics & Percentage \\
\hline Western Atlantic (WA) & 1023 & 881 & 86.1 \\
\hline Northwestern Atlantic (NWA) & 831 & 473 & 56.9 \\
\hline Caribbean & 814 & 272 & 33.4 \\
\hline Southwestern Atlantic (SWA) & 471 & 118 & 25.1 \\
\hline Brazilian coast & 437 & 46 & 10.5 \\
\hline Mid-Atlantic Ridge (MAR) & 111 & 29 & 26.1 \\
\hline Eastern Atlantic (EA) & 551 & 352 & 63.9 \\
\hline Tropical Eastern Atlantic (TEA) & 388 & 117 & 30.6 \\
\hline Southwestern Indian Ocean (SWIO) & 1141 & - & - \\
\hline
\end{tabular}

${ }^{*}$ See Table 1 for definitions of the areas.



Figure 1 Reef fish richness patterns in the Atlantic Ocean and adjacent areas. Circle diameters are sized in proportion to the number of species in each area. The largest circle inside the Atlantic represents 750 species in the Western Caribbean plus Florida.

species from South Africa's tropical Indian Ocean, resulting in a total of 2605 species. Encompassing the Greater Caribbean, the Northwestern Atlantic (NWA) has the highest number of species and genera in the Atlantic (831 species - Table 2 and Fig. 1; 150 genera - Table 3, based on selected speciose families). This number is dominated by Caribbean species with tropical affinities (814). The endemism figures are high for these areas (species: 57\% NWA and 33\% Caribbean; genera: $16 \%$ for both the Caribbean and the NWA). When considered separately, the western Caribbean plus Florida ('Caribbean Province' sensu Briggs, 1974) and the eastern Caribbean ('West Indian Province' sensu Briggs, 1974) have essentially identical levels of endemism, each with c. 50 (or c. 7\%) endemic species. This is much lower than the $19 \%$ endemism rate of the 'West Indian Province' found back in 1974 (Briggs, 1974).

The Southwestern Atlantic (SWA; Brazilian oceanic islands and Argentina included) has slightly over half (471) of the species richness of its northwest counterpart, and a somewhat lower, but still substantial, rate of endemism (25\%). This endemism rate of the Brazilian coast plus its oceanic islands provides the basis for distinguishing the 'Brazilian Province', first proposed by Briggs (1974, 1995; see also Floeter \& Gasparini, 2000; Joyeux et al., 2001). When only the Brazilian coast is considered, the endemism level drops to c. $10 \%$ (see also Rocha, 2003). Within coastal Brazil, the northeast coast has nine endemic species $(2.3 \%$ of the total richness), and the southeast coast has eight endemics (2.1\%). The SWA contains 117 genera, $78 \%$ of the Caribbean number, with only three endemic genera $(2.6 \%)$, vs. $16 \%$ of endemic genera in the Caribbean.

The Mid-Atlantic Ridge (MAR) islands of Ascension and St Helena harbour 111 reef fish species, with 29 (26.1\%) endemics, justifying the province proposed by Briggs (1974, 1995).

The Eastern Atlantic (EA; from the Mediterranean to the Benguela region) has 551 species (124 genera), with $64 \%$ of these species (31.5\% of genera) restricted to this side of the Atlantic (Tables 2 and 3). The tropical area of the EA (Cape Verde Islands, São Tomé, and the West African coast from Cape Verde in Senegal to Moçamedes in Angola) includes 388 species (106 genera), and the endemism rate is c. $30 \%$ for species $(3.8 \%$ for genera). Thus, the species and genera richness in the tropical EA (TEA) is considerably lower than that of the tropical Western Atlantic (WA), which is consistent with earlier literature (e.g. Briggs, 1974, 1995; Paulay, 1997).

In comparison, the species richness of the tropical Eastern Pacific (TEP) is approximately $89 \%$ of the richness of the Caribbean (Robertson, 1998; Fig. 1). The number of species of reef fishes found in tropical South Africa is about 1140, but only $20 \%$ of these are also found in the Atlantic Ocean, mainly in the Agulhas area. Approximately 5\% are found in tropical areas of the Atlantic.

The relative impoverishment of the Atlantic fauna compared with that of the Indo-West Pacific (Paulay, 1997; Bellwood \& Wainwright, 2002) probably reflects the much smaller geographical scale of the region and the historical changes that have impacted reefs, especially in the wider Caribbean (Vermeij, 2001, 2005; Johnson et al., 2007). There is no doubt that the reef biota of this region has been subject to wide-scale disturbances and episodic extinctions, with the consequence that the present-day assemblages are less diverse than those of the Miocene (Budd, 2000). Based on skeletonized groups, it seems that Pliocene extinctions were severe in the Western Atlantic, where many groups underwent 20 to $30 \%$ genus-level extinction (Vermeij, 2001, 2005). The closure of the Isthmus also modified the oceanographic regime of the western Caribbean, with a change from cooler upwelling to a warmer oligotrophic regime (Johnson et al., 2007). Moreover, Pleistocene glaciations that squeezed the tropical regions and the area of shallow-water habitats (Bellwood \& Wainwright, 2002) are also thought to be related to the relative paucity of species in the tropical Atlantic provinces, even when compared with the south-western Indian Ocean (Table 2). However, in the 
Table 3 Selected speciose families - total number of genera per family and genera restricted to single regions (in parentheses). NW, New World (TEP + WA); TEP, Tropical Eastern Pacific; WA, Western Atlantic; Braz., Brazil; Carib., Caribbean; EA, Eastern Atlantic; Med, Mediterranean; Cape + SWIO, South African's Cape + Indian Ocean. Indones., Indonesia (based on Allen \& Adrim, 2003) is included for comparison purposes.

\begin{tabular}{|c|c|c|c|c|c|c|c|c|c|c|}
\hline Family & NW & $\mathrm{TEP}^{1}$ & $\mathrm{WA}^{2}$ & Braz. $^{3}$ & Carib. & $\mathrm{EA}^{4}$ & TEA & Med & Cape+IO* & Indones. $\dagger$ \\
\hline Apogonidae & $3(1)$ & 1 & $3(1)$ & 3 & 3 & 2 & 2 & 1 & $12(11)$ & 14 \\
\hline Balistidae & 6 & 6 & 4 & 4 & 4 & 4 & 4 & 1 & $12(6)$ & 10 \\
\hline Batrachoididae & $7(7)$ & $3(2)$ & $5(5)$ & $5(1)$ & $5(1)$ & 2 & 2 & 1 & $5(2)$ & 2 \\
\hline Blenniidae & $10(4)$ & $7(2)$ & $7(1)$ & 6 & $7(1)$ & $13(3)$ & $10(1)$ & 9 & $21(18)$ & 28 \\
\hline Carangidae & $10(1)$ & 9 & $10(1)$ & $10(1)$ & 8 & $11(1)$ & 9 & 7 & $9(1)$ & 14 \\
\hline Chaenopsidae & $13(13)$ & $10(3)$ & $10(3)$ & 3 & $10(2)$ & - & - & - & - & - \\
\hline Dactyloscopidae & $8(8)$ & $6(1)$ & $7(2)$ & $4(1)$ & $6(1)$ & - & - & - & - & - \\
\hline Gobiesocidae & $6(6)$ & 3 & $6(6)$ & 5 & $6(1)$ & $5(3)$ & $5(1)$ & $5(1)$ & $6(3)$ & 5 \\
\hline Gobiidae & $26(14)$ & 13 & $25(14)$ & 15 & $25(8)$ & $19(16)$ & 14 & $19(8)$ & $50(43)$ & 50 \\
\hline Haemulidae & 3 & 3 & 3 & 3 & 3 & $3(1)$ & 3 & 2 & $2(1)$ & 2 \\
\hline Labridae & $8(2)$ & 7 & $8(2)$ & 7 & $8(1)$ & $11(5)$ & 9 & 8 & $29(25)$ & 35 \\
\hline Labrisomidae & $7(3)$ & $6(2)$ & $5(1)$ & 4 & $5(1)$ & 2 & 2 & - & - & - \\
\hline Lutjanidae & $7(3)$ & 2 & $6(3)$ & 5 & 6 & 3 & 3 & - & $7(4)$ & 8 \\
\hline Muraenidae & $11(1)$ & $9(1)$ & 8 & 7 & 8 & 8 & 7 & 4 & $12(6)$ & 12 \\
\hline Pomacentridae & $7(3)$ & $7(3)$ & 4 & 4 & 4 & $5(1)$ & $5(1)$ & 1 & $13(10)$ & 19 \\
\hline Pseudochromidae & - & - & - & - & - & - & - & - & $6(6)$ & 11 \\
\hline Scaridae & $4(1)$ & 3 & $4(1)$ & 4 & 4 & 3 & 3 & 1 & $6(4)$ & 7 \\
\hline Serranidae & $27(16)$ & 15 & $27(15)$ & 15 & $23(7)$ & $12(1)$ & 11 & 5 & $25(15)$ & 21 \\
\hline Sparidae & $6(3)$ & 2 & $6(1)$ & 4 & 5 & $12(4)$ & $12(1)$ & 10 & $21(13)$ & - \\
\hline Syngnathidae & $10(3)$ & 5 & 9 & 8 & $9(1)$ & $8(3)$ & 4 & 4 & $15(10)$ & 18 \\
\hline Tripterygiidae & $4(3)$ & $4(3)$ & 1 & 1 & 1 & $1(1)$ & 1 & 1 & $5(5)$ & 5 \\
\hline No. genera (endemic) & $183(92)$ & $121(17)$ & $158(56)$ & $117(3)$ & $150(24)$ & $124(39)$ & $106(4)$ & $79(9)$ & $256\left(177^{\star}\right)$ & $261 \dagger$ \\
\hline Percent endemic genera & 50.3 & 14.0 & 35.4 & 2.6 & 16.0 & 31.5 & 3.8 & 11.4 & $69.1^{*}$ & - \\
\hline
\end{tabular}

1: Eastward-migrant tropical transpacific Pacific genera that occur in the TEP but not the WA or SWIO are not counted as TEP genera.

2: Genera known only from southern Brazil are included in counts of TWA-restricted genera.

3: Including Argentina.

4: Including Macaronesian and Mediterranean (some extending north in the Northeastern Atlantic) genera, except endemic Mediterranean genera. ${ }^{\star}$ Numbers in parentheses do not represent strict endemism, but genera not found in the Atlantic and the TEP.

$\dagger$ Coral reef fishes only.

absence of a good fossil record, there is almost no direct evidence of extinction in reef fishes.

Apart from the high endemism of Ascension and St Helena (Table 4), endemism rates on oceanic islands vary from zero in Madeira (although there are two endemic species shared with the Canaries and one with the Azores), to $1.1 \%$ in the Azores, $1.8 \%$ in Bermuda, $1.6 \%$ in the Canaries, c. 3\% in São Tomé and Príncipe (plus Annobon), 5\% in Atol das Rocas plus Fernando de Noronha, 5.7\% at Trindade Island, $8.3 \%$ in the Cape Verde Islands, and 9.3\% at St Paul's Rocks.

Various combinations of island age, geographic isolation, area of available habitat and patterns of oceanic currents connecting these islands to potential source areas are probably involved in producing the relatively low endemism in the non-MAR islands (Table 4; Briggs, 1966; Smith-Vaniz et al., 1999; Gasparini \& Floeter, 2001; Rocha, 2003; Wirtz et al., 2007). The low level of endemism at Bermuda, the Canaries, and other high-latitude locations seems to indicate extirpation during Pleistocene glacial periods and recent recolonization (Briggs, 1966; Smith-Vaniz et al., 1999; Rocha, 2004; Domingues et al., 2006, 2007), with little time for subsequent speciation. In the Tropics, the intermediate endemism rates of 3-6\% at São Tomé and Príncipe, Fernando de Noronha Ridge and Trindade Island probably result from the proximity $(<1000 \mathrm{~km})$ to continental margins, and/or connections to mainland areas via seamounts. In contrast, the high endemism at the Cape Verde Islands may be related to: (1) greater isolation (from the mainland and between islands), (2) high heterogeneity of habitats (Pérez-Ruzafa et al., 2005), and (3) maintenance of warm tropical waters in glacial periods. The genus Diplodus is thought to have originated in this archipelago (Summerer et al., 2001), as well as the only endemic Atlantic damselfish genus (Similiparma) and the monotypic genus Virididentex (Sparidae). The Cape Verde Islands are also known for high diversity and endemism in tropical marine invertebrates, including several endemic species in the gastropod genus Conus (Cunha et al., 2005; Duda \& Rolán, 2005). The high endemism of St Paul's Rocks is related to geographic isolation and overall low species richness (five of the 54 species are endemics, whereas 17 of the 205 Cape Verde species are endemics). Despite having three species shared only with Ascension and St Helena on the 
Table 4 Endemism rates of reef fishes and characteristics of the oceanic islands of the Atlantic Ocean.

\begin{tabular}{|c|c|c|c|c|c|c|c|c|c|c|}
\hline Island & $\begin{array}{l}\text { Endemism } \\
(\%)\end{array}$ & $\begin{array}{l}\text { Richness } \\
\text { ( } n \text { species) }\end{array}$ & Latitude & $\begin{array}{l}\text { Distance } \\
\text { from } \\
\text { mainland } \\
(\mathrm{km})\end{array}$ & $\begin{array}{l}\text { Isolation } \\
\text { from } \\
\text { nearest reef } \\
\text { habitat }(\mathrm{km})\end{array}$ & $\begin{array}{l}\text { Maximum } \\
\text { distance inside } \\
\text { the archipelago } \\
(\mathrm{km})\end{array}$ & $\begin{array}{l}\text { Shelf } \\
\text { surface } \\
\left(\mathrm{km}^{2}\right)\end{array}$ & $\begin{array}{l}\text { Age } \\
\text { (Ma) }\end{array}$ & $\begin{array}{l}\text { Ice age } \\
\text { effects* }\end{array}$ & $\begin{array}{l}\text { Diversity } \\
\text { of } \\
\text { habitats }\end{array}$ \\
\hline St Helena & 13.2 & 76 & $16^{\circ} \mathrm{S}$ & 1870 & $1290 \dagger$ & - & 156 & 10 & No & Low \\
\hline Ascension & 11.0 & 82 & $8^{\circ} \mathrm{S}$ & 1536 & $1290 \ddagger$ & - & 106 & 1.5 & No & Low \\
\hline St. Paul's Rocks & 9.3 & 52 & $1^{\circ} \mathrm{N}$ & 1010 & $630 \$$ & - & $1 ?$ & 9.3 & No & Low \\
\hline Cape Verde Is. & 8.3 & 207 & $16^{\circ} \mathrm{N}$ & 560 & Mainland & 365 & 13,991 & 10.3 & No & High \\
\hline Trindade Is. & 5.7 & 85 & $20^{\circ} \mathrm{S}$ & 1160 & 300 & 47 & 32 & 3.6 & No & Low \\
\hline F. de Noronha Ridge & 5.0 & 120 & $4^{\circ} \mathrm{S}$ & 350 & Mainland & 150 & $27^{\star *}$ & 12 & No & Interm. \\
\hline Sao Tomé \& Príncipe & 3.0 & 221 & $1^{\circ} \mathrm{N}$ & 250 & $210 \dagger \dagger$ & 140 & 860 & 31 & No & High \\
\hline Bermuda & 1.6 & 280 & $32^{\circ} \mathrm{N}$ & 1049 & Mainland & - & 1204 & 60 & Yes & High \\
\hline Canaries & 1.6 & 182 & $28^{\circ} \mathrm{N}$ & 100 & Mainland & 490 & 8027 & 20.5 & Yes & High \\
\hline Azores & 1.1 & 95 & $38^{\circ} \mathrm{N}$ & 1300 & $740 t t$ & 675 & 5363 & $0.2-7$ & Yes & High \\
\hline Madeira & 0.0 & 133 & $33^{\circ} \mathrm{N}$ & 630 & $285 \$ \S$ & 96 & 810 & 15 & Yes? & Interm. \\
\hline
\end{tabular}

${ }^{*}$ Only temperature effects.

$\dagger$ To Ascension.

$\$$ To St Helena.

§o F. de Noronha.

$\uparrow$ To seamounts of the Vitória-Trindade Chain.

${ }^{*}$ Noronha only.

$\dagger \dagger$ To Fernando Poo (=Bioko).

\$To Madeira.

§To Selvagem Islands.

MAR, all the other components of St Paul's Rocks are shared with the Brazilian coast or the Fernando de Noronha Ridge (Feitoza et al., 2003). Thus, all the Brazilian oceanic islands are considered here as impoverished outposts of the Brazilian Province (Fig. 4; Edwards \& Lubbock, 1983; Floeter \& Gasparini, 2000).

\section{Composition of the faunas}

Species richness varies greatly among biogeographical regions, not only in terms of total numbers, but also in the relative contributions from each taxonomic family (Fig. 2). Some features are immediately apparent.

(1) Overall patterns of species richness per family in the NWA and SWA are similar but each family is consistently more diverse in the NWA, especially families of small cryptobenthic fishes. Three of the most speciose families of Neotropical reef fishes have far more species in the NWA than in the SWA (Gobiidae with 91 vs. 27; Labrisomidae with 46 vs. 16; and Chaenopsidae with 51 vs. 4). This is not the case with other species-rich groups that are not restricted to the Neotropics: the Labridae, Scorpaenidae, Haemulidae and Carangidae have comparable numbers in both areas, and Pinguipedidae has more species in the SWA.

(2) The EA areas (TEA and NEA) have very similar patterns but differ greatly from the WA areas. Two speciose families, Sparidae and Blenniidae, are markedly more speciose in both parts of the EA than in the WA (40 vs. 21 and 43 vs. 24). However, two of the four most speciose families in the WA are absent or very poorly represented in the EA (Chaenopsidae is absent; and Labrisomidae has only two species). The MAR islands are more similar to the EA than to the WA. Two pantropical families are relatively (percentage of the total fauna) more speciose in the MAR than elsewhere in the Atlantic, namely Muraenidae and Carangidae.

(3) The southwestern Indian Ocean (SWIO) exhibits a highly distinctive pattern, with several families being more important there than in the Atlantic areas (e.g. Acanthuridae, Apogonidae, Clinidae, Labridae, Pomacentridae); several families are unrecorded in the Atlantic (e.g. Caesionidae, Nemipteridae, Pseudochromidae, Siganidae); and some families that are important in the Atlantic faunas are lacking in the SWIO (Chaenopsidae, Dactyloscopidae, Grammatidae, Labrisomidae).

Some genera have highly skewed distributions (Fig. 3). For example, 156 genera occur in the New World (NW - both sides of tropical America) but not in the EA (e.g. Anisotremus, Calamus, Elacatinus, Haemulon, Halichoeres ('Iridio' clade), Lythrypnus, Ogcocephalus, and Opistognathus). Other genera, such as Malacoctenus, Mycteroperca, Sparisoma and Stegastes (Fig. 3), are much more diverse in the WA (and the TEP) than in the EA. However, Diplodus, Parablennius and Scartella are more speciose in the EA than in the WA. Eighty-four genera occurring in the EA (not considering southern Africa) are not found in the WA (e.g. Gobius, Lipophrys, Pagellus, Spicara, Symphodus, Thorogobius, Wheelerigobius). Eighteen EA genera occur in the Indo-Pacific but not in the WA or TEP (e.g. Branchiostegus, Callionymus, Coris, Lethrinus, Periophthalmus, Plectorhinchus), indicating a historical connection via southern Africa or Tethys relicts. 

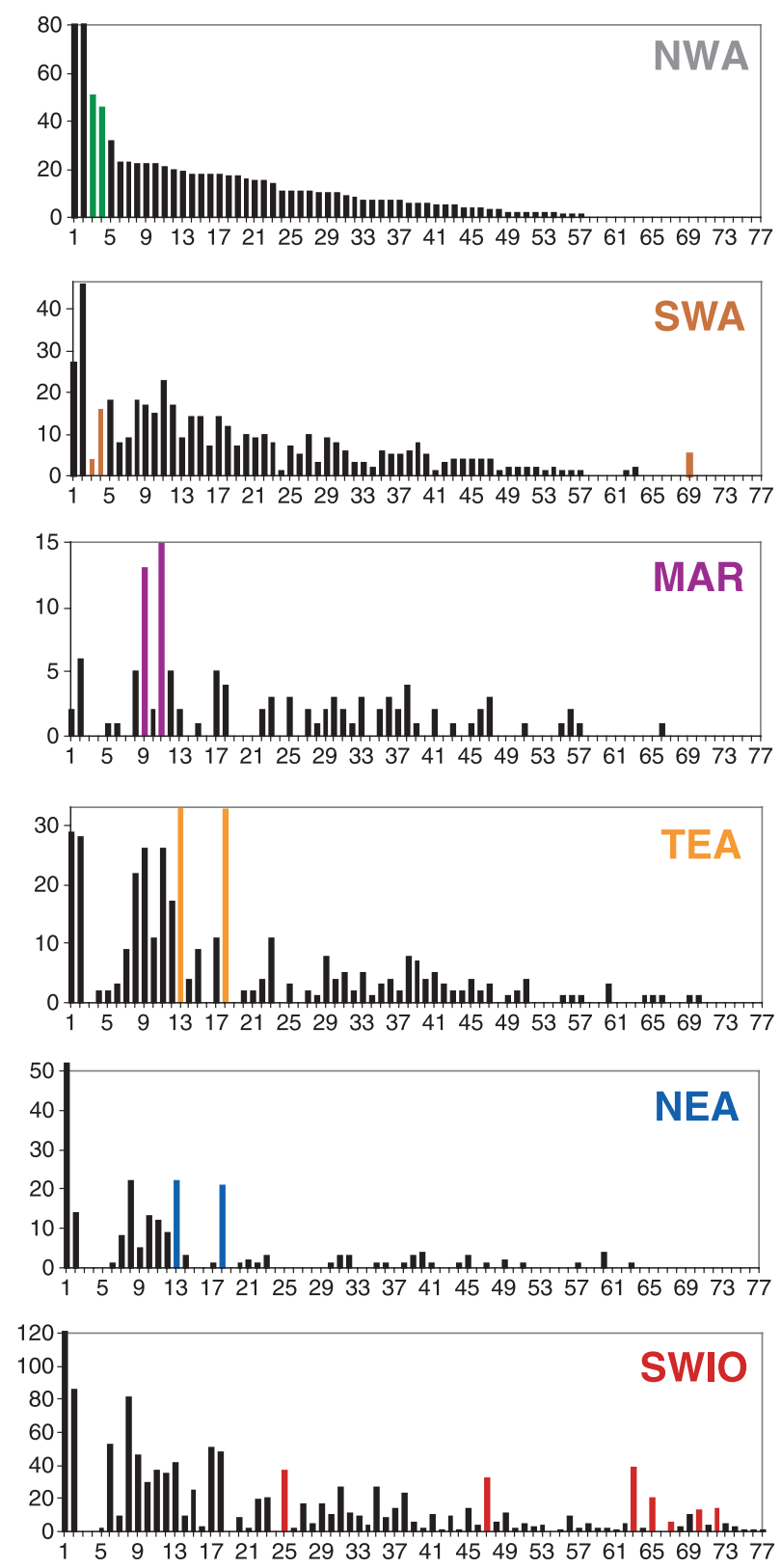

A few genera show disjunct distributions that indicate either extinction in the WA or colonization of the EA from the IO. For example, Cirrhitus, Girella and Prionurus are found in the EA, Indo-West Pacific and TEP but not in the WA. Tyler (1997) reported a Caribbean fossil of the putative sister taxon of the surgeonfish genus Naso, providing direct evidence for the extinction scenario (today, no member of the Naso lineage is found in the Atlantic). The relationship between these patterns of diversity and the origin of genera will be discussed later.

\section{Relationships among areas and biogeographical barriers/filters}

The maximum-parsimony analysis using the presence/absence species distribution data base illustrates relationships among the WA (further subdivided into the NWA and SWA), the EA
Figure 2 Species richness, by family, for the five major Atlantic biogeographical regions and the Southwestern Indian Ocean. NWA: Northwestern Atlantic, SWA: Southwestern Atlantic, MAR: Mid-Atlantic Ridge (Ascension + St Helena), EA: Eastern Atlantic, TEA: Tropical Eastern Atlantic, NEA: Northeastern Atlantic, SWIO: South Africa's tropical Indian Ocean (from Kei River to Kosi Bay). The ordering of families in each region follows the ranking of those families in the NWA. Coloured bars (and bold below) indicate families that are disproportionally more important in one or more specific regions. Families: 1, Gobiidae; 2, Serranidae; 3, Chaenopsidae; 4, Labrisomidae; 5, Paralichthyidae; 6, Apogonidae; 7, Gobiesocidae; 8, Labridae; 9, Muraenidae; 10, Syngnathidae; 11, Carangidae; 12, Scorpaenidae, 13, Sparidae; 14, Haemulidae; 15, Lutjanidae; 16, Opistognathidae; 17, Pomacentridae; 18, Blenniidae; 19, Dactyloscopidae; 20, Batrachoididae, 21, Ophidiidae; 22, Scaridae; 23, Bothidae; 24, Grammatidae; 25 , Holocentridae; 26, Ogcocephalidae; 27, Ophichthidae; 28, Malacanthidae; 29, Monacanthidae; 30, Synodontidae; 31, Tetraodontidae; 32, Tripterygiidae; 33, Antennariidae; 34, Bythitidae; 35. Chaetodontidae; 36, Diodontidae; 37, Pomacanthidae; 38, Balistidae; 39, Congridae; 40, Sciaenidae; 41, Callionymidae; 42, Microdesmidae; 43, Ostraciidae; 44, Chlopsidae; 45, Mullidae; 46, Priacanthidae; 47, Acanthuridae; 48, Ptereleotridae; 49, Carapidae; 50, Fistulariidae; 51, Kyphosidae; 52, Moringuidae; 53, Pempheridae; 54, Uranoscopidae; 55, Aulostomidae; 56, Cirrhitidae; 57, Dactylopteridae; 58, Caesionidae; 59, Caracanthidae; 60, Centracanthidae; 61, Chanidae; 62, Cheilodactylidae; 63, Clinidae; 64, Kuhliidae; 65, Lethrinidae; 66, Myrocongridae; 67, Nemipteridae; 68, Pentacerotidae; 69, Pinguipedidae; 70, Platycephalidae; 71, Plesiopidae; 72, Pseudochromidae; 73, Siganidae; 74, Synanceiidae; 75, Trichonotidae; 76, Xenisthmidae; 77, Zanclidae.

(further subdivided into the NEA, TEA, Benguela, MAR and Cape) and the South African Indian Ocean (Fig. 4). Despite the Amazon filter, the SWA and NWA have the greatest number of species and genera in common (348 and 201, respectively, including a total of 55 families; Fig. 5). These species represent $42 \%$ of the NWA total reef fish fauna and $74 \%$ of the SWA fauna (Fig. 5). If closely related species pairs $(n=30$; Table S2) are included in the calculations, their representation increases to $45 \%$ and $82 \%$, respectively (Fig. 6).

Another way to look at the effectiveness of Atlantic biogeographical barriers/filters is to examine the proportional representation of trans-barrier species within each family (Figs 6-8). Notably, families Serranidae and Carangidae have the greatest number of species crossing the Amazon filter. With the exception of gobiids, the families containing trans-Amazonian species are mostly pelagic spawners with medium to large body sizes. Demersal-spawning and brooder families with small-bodied cryptobenthic species seem to be the most affected by the Amazon freshwater and sediment discharge (e.g. Chaenopsidae, Gobiidae). Most of these families are disproportionately more diverse on Caribbean coral reefs than in the SWA (Floeter \& Gasparini, 2000; Moura \& Sazima, 2003; Rocha, 2003). The second highest exchange is between the EA and the WA (NWA and SWA areas with $c .106$ species in each link). In total, we recorded 112 species with transAtlantic distributions (Fig. 7). This corresponds to approxi- 




Figure 3 Richness patterns of six selected genera in the Atlantic Ocean and adjacent areas. Circle diameters are sized proportionally to the number of species in each area. The maximum number of species is given (in the largest circle) for comparison. mately three times fewer trans-Atlantic species than transAmazon species $(n=348)$. Relative to the total fauna, these species comprise $11.8 \%$ of the WA fauna ( $23 \%$ of the SWA and $13 \%$ of the NWA), $20 \%$ of the EA, and $45 \%$ of the MAR islands fish fauna.

When the TEA is considered separately, the proportion of trans-Atlantics rises to $27 \%$ of the fauna. If putative sister species are included as trans-Atlantic units (species that have their closest relatives on the other side of the Atlantic Ocean; Table S2), the proportion of trans-Atlantic fish taxa in the TEA increases to $38 \%$ of the fauna, a proportion close to that of the MAR. The number of reef fish species common to the MAR (Ascension + St Helena) and the EA $(n=64)$ or common to the MAR and the SWA $(n=71)$ constitute $c .60 \%$ of the MAR fish fauna (Fig. 5).

The majority of trans-Atlantic species belong to families of pelagic-spawners with long pelagic larval durations (PLDs; e.g. Muraenidae, Serranidae; Victor, 1991) and/or fishes that are known rafters (e.g. Balistidae, Carangidae, Diodontidae, Monacanthidae). Entire families in the MAR and TEA are composed of trans-Atlantic species (e.g. Diodontidae, Holocentridae, Priacanthidae, Synodontidae). If trans-Atlantic sister species are considered, 16 families in the TEA are composed only of these wide-ranging taxa (Fig. 7). Detailed statistical analyses involving several biological attributes of reef fishes crossing barriers in the Atlantic will be published elsewhere.

The weakest connection across a soft barrier corresponds to the Benguela Current filter, represented by 47 species (38 shared with the TEA - plus 22 putative sister species, and 9 shared with the SWA). Relative to the total fauna of each side, the 60 species and sister species in common comprise $16 \%$ of TEA fishes but only $5 \%$ of SWIO. These numbers indicate that the strength of the connection between the Indo-Pacific and the EA has previously been underestimated (Briggs, 1974, 1995). Examples from other taxonomic groups with a good fossil record reinforcing the relationships between the IO (and/ or the IWP) and the TEA include gastropods, bivalves, and opisthobranch molluscs (Edmunds, 1977; Oliver and von Cosel, 1992; Vermeij \& Rosenberg, 1993).

The link between the IO and SWA has been underappreciated in previous analyses (but see Vermeij \& Snyder, 2003 for gastropod examples). The nine shared species are few in comparison to the total number of species in each area, but reveal a possible connection across the South Atlantic. The 


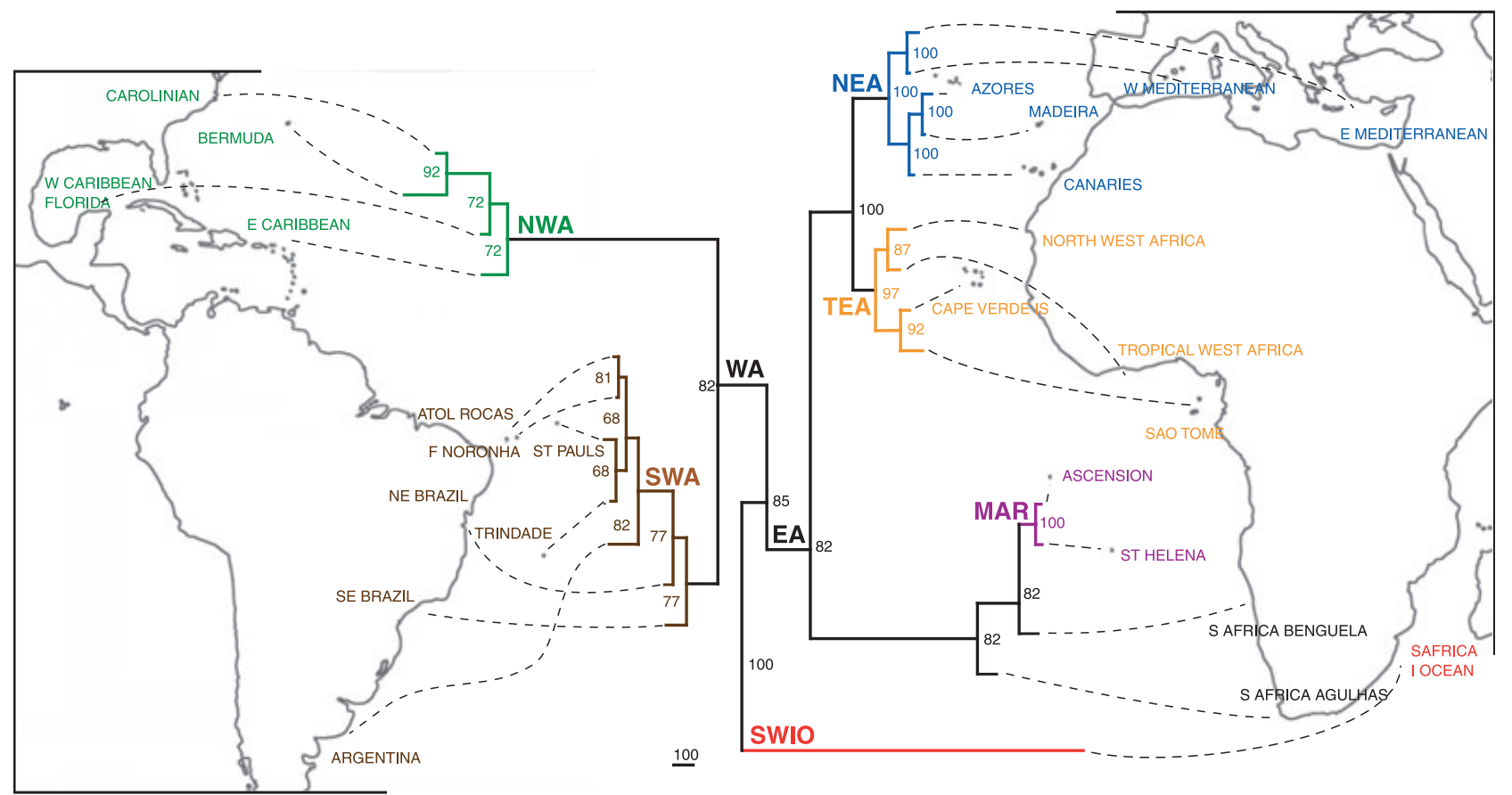

Figure 4 Relationships of 25 areas in the Atlantic Ocean based on maximum-parsimony analysis using the presence/absence distribution data base of 2605 reef fish species. Values at nodes represent bootstrap support (1000 replicates). Consistency index $=0.499$, homoplasy index $=0.501$ and retention index $=0.620$.

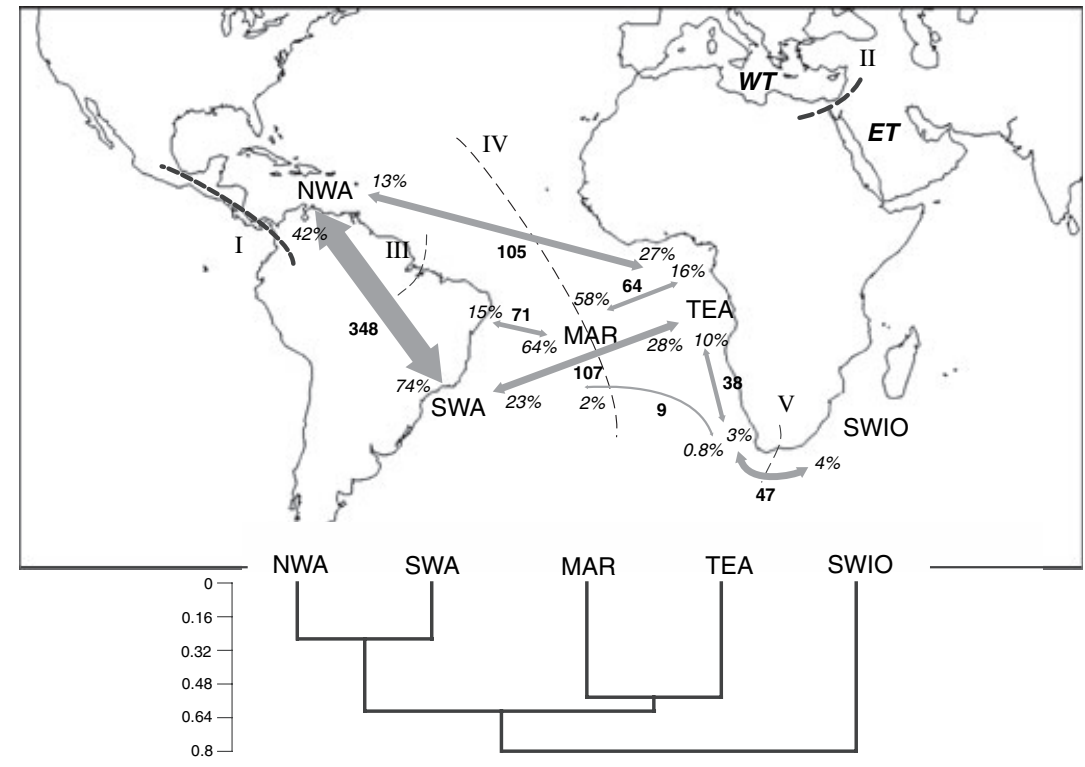

Figure 5 Biogeographical barriers and relationships among areas based on the number of reef fish species common to each pair of areas. Hard barriers: (I) Isthmus of Panama, 3.1-3.5 Ma (II) Terminal Tethyan Event (Red Sea land bridge), 12-18 Ma. Soft barriers: (III) Amazon discharge, 6-10 Ma; (IV) Mid-Atlantic Barrier, 0-60 Ma; (V) Benguela Barrier, 2 Ma. Areas/provinces: WT, West Tethys; ET, East Tethys. NWA, Northwestern Atlantic (Caribbean + Bermuda + Carolinian); SWA, Southwestern Atlantic (Brazil + Brazilian oceanic islands + Argentina); MAR, Mid-Atlantic Ridge (Ascension + St Helena); EA, Eastern Atlantic (Macaronesia + Gulf of Guinea); SA, South Africa (tropical Indian Ocean). Arrow widths are sized proportionally to the number of species common to the areas. The proportion of the number of species common to a pair of areas relative to its entire reef fish fauna is given at each end of the arrows. In order to summarize the relationships among the areas, a cluster analysis (Bray-Curtis dissimilarity index; UPGMA method) based on the matrix of the number of shared species among areas indicating the importance of the biogeographical connections is shown at the bottom. Varying the clustering routine has no effect on the grouping of the sites. The link between the SWIO and the Atlantic (47 species) is further divided into two: 38 with the TEP and 9 with the SWA. 


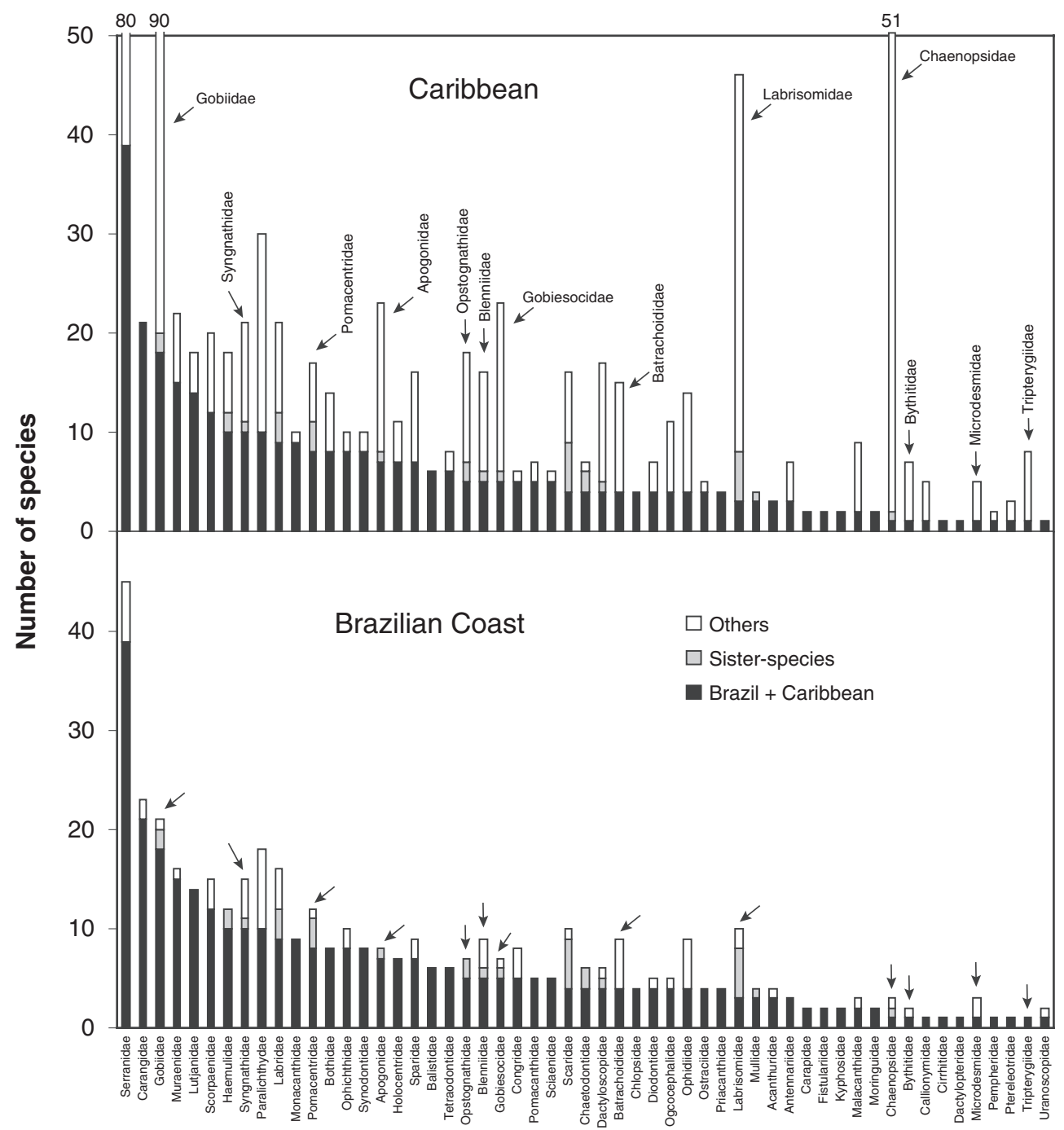

Figure 6 Distributions of species in families of fishes across the Amazon Barrier: numbers of species found on both sides of the barrier (Brazil + Caribbean); numbers of species that have their closest relative on the other side of the barrier (sisters); and numbers of species found on one side that have no known sisters on the other side of the barrier (other). Demersal-spawning and brooder families are indicated with arrows.

recent record of the starry toadfish Arothron firmamentum in Argentinian waters (Díaz de Astarloa et al., 2003) and at St Paul's Rocks (L. Fritzsche, personal communication) exemplifies this route via the South Atlantic gyre. Two recent population genetic surveys support the direct recent (post Benguela-establishment) colonization of the SWA by an IO goby (genus Gnatholepis, Rocha et al., 2005a) and angelfish (genus Centropyge, Bowen et al., 2006a). There are also examples of an IO genus found at St Helena and Ascension but nowhere else in the Atlantic (Helcogramma sp.; HadleyHansen, 1986; Heemstra \& Heemstra, 2004), and there is an assumed invasion of the Atlantic by Chaetodon sedentarius from the western IO C. dolosus clade at around 1.6 Ma (Fessler \& Westneat, 2007).

A cluster analysis based on the shared species synthesized the overall pattern closely linking the NWA to the SWA, and the
MAR to the EA (Fig. 5), in a similar fashion to the maximumparsimony analysis (Fig. 4).

The number of species shared only between the NWA and the SWA $(n=225)$ is the highest among all pairwise comparisons; these species are proportionately more dominant in the SWA than in the NWA ( $48 \%$ vs. $27 \%$ ). Eleven species are found only in the EA and the MAR (e.g. Acanthostracion notacanthus, Gymnothorax unicolor, Myroconger compressus, Xyrichtys sanctaehelenae), comprising $10 \%$ of the total MAR fauna.

The SWIO and the TEA share 15 species (plus 11 putative sister-species pairs totalling c. $10 \%$ of the EA fauna), for example Gymnothorax margaritophorus and Rhabdosargus globiceps (both with wider distributions in the Indo-Pacific), and Lithognathus mormyrus and Sarpa salpa (with a putative EA origin owing to their wider distributions in this area). An additional 52 species with subtropical affinities are distributed 
Figure 7 Distributions of species in families of fishes across the Mid-Atlantic Barrier, and at the Mid-Atlantic Ridge islands (Ascension and St Helena): numbers of species found on both sides of the barrier (Amphiatlantic); numbers of species that have their closest relative on the other side of the barrier or on the Mid-Atlantic Ridge Islands (sisters); and numbers of species found on one side that have no known sisters on the other side of the barrier (other). Species recorded as vagrants were also included.

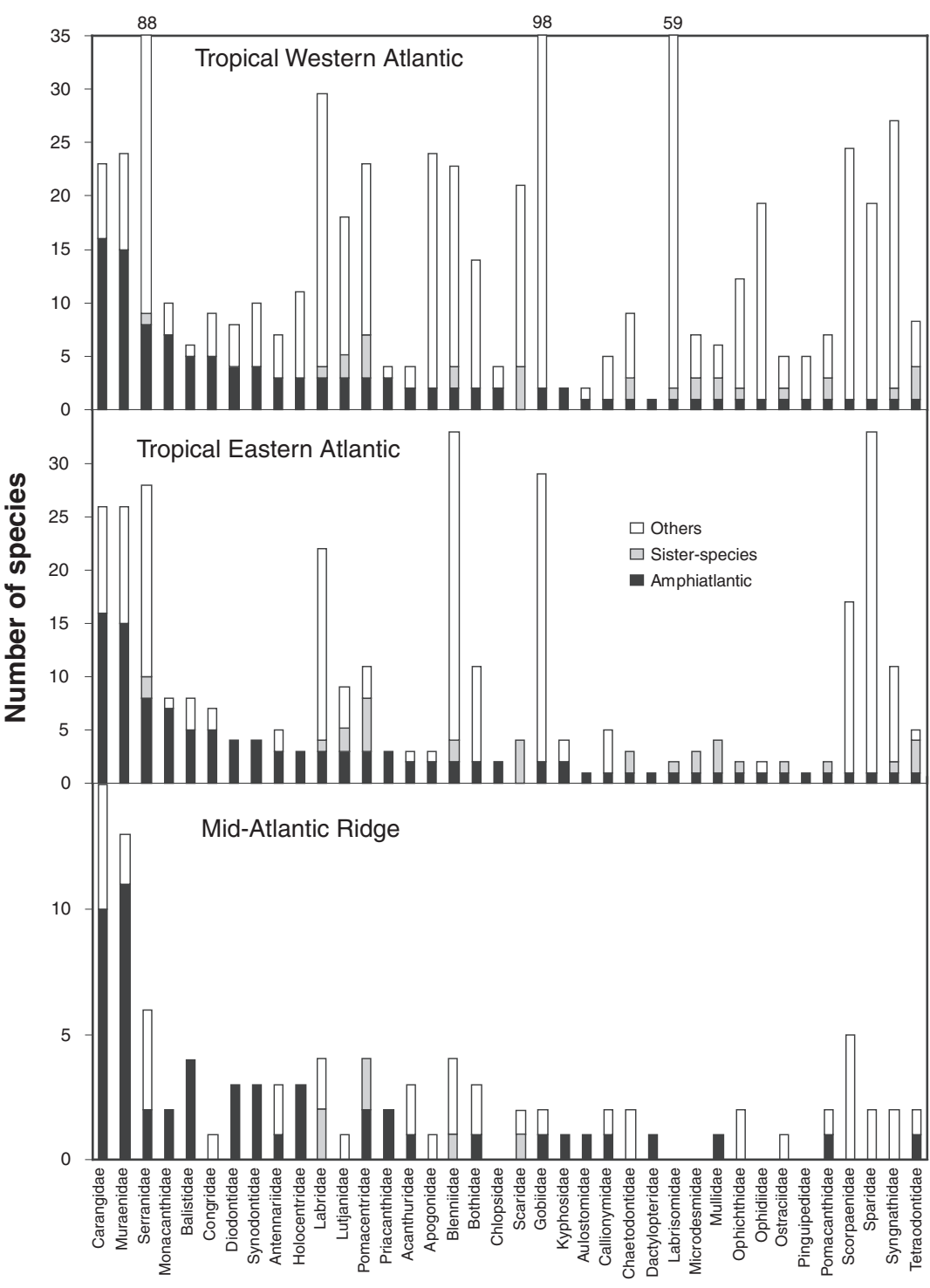

along the South African coast from the Agulhas to the Benguela region (Namibia and southern Angola). However, these species do not reach tropical waters. A few are also found in the NEA and/or the Mediterranean, thus representing antitropical distributions (e.g. Sparidae). A cluster analysis summarizing the overall pattern of shared-only taxa (not shown) closely linked the NWA to the SWA as in Fig. 5, but with the IO and the EA closely related, and the MAR between the two clusters.

A cluster analysis of genera (Fig. 9) revealed a pattern similar to that of the species cluster analysis (Fig. 4). At this taxonomic level, however, we were able to include the TEP, which clustered with the WA as expected. The TEP and the NWA have 155 genera in common, the NWA and the SWA have 144, the TEA and WA have 110, and the TEA and South Africa's Indian Ocean have 94. The generic endemism rate is very high $(50.3 \%)$ in the New World (TEP + WA) and in the EA as a whole (31.5\%; Table 3). Within these major regions, $16 \%$ of the Caribbean genera are endemic, followed by $14 \%$ in the TEP, $11.4 \%$ in the Mediterranean, $3.8 \%$ in the TEA, and $2.6 \%$ in the SWA.

\section{Subtropical and temperate areas}

The subtropical and warm-temperate areas included in our analysis are impoverished outposts of adjacent tropical areas. For example, the Carolinian Province (sensu Smith-Vaniz et al., 1999) and Argentina (see Irigoyen et al., 2005) clustered with oceanic islands of the nearest contiguous tropical region (Fig. 4). Despite some recognized endemism (although taxonomically restricted to eight Gobiidae genera plus one Gobiesocidae genus; Table 3), the Mediterranean Sea has a marine fauna related to the Macaronesian Islands and the northeastern Atlantic coast (Gonçalves et al., 1993, 2005; Briggs, 1995; Almada et al., 2001). South Africa's Benguela (the 'Southwest Africa' province of Briggs, 1974) and Agulhas provinces grouped with Ascension and St Helena, possibly as a result of their common low diversity rather than of their 


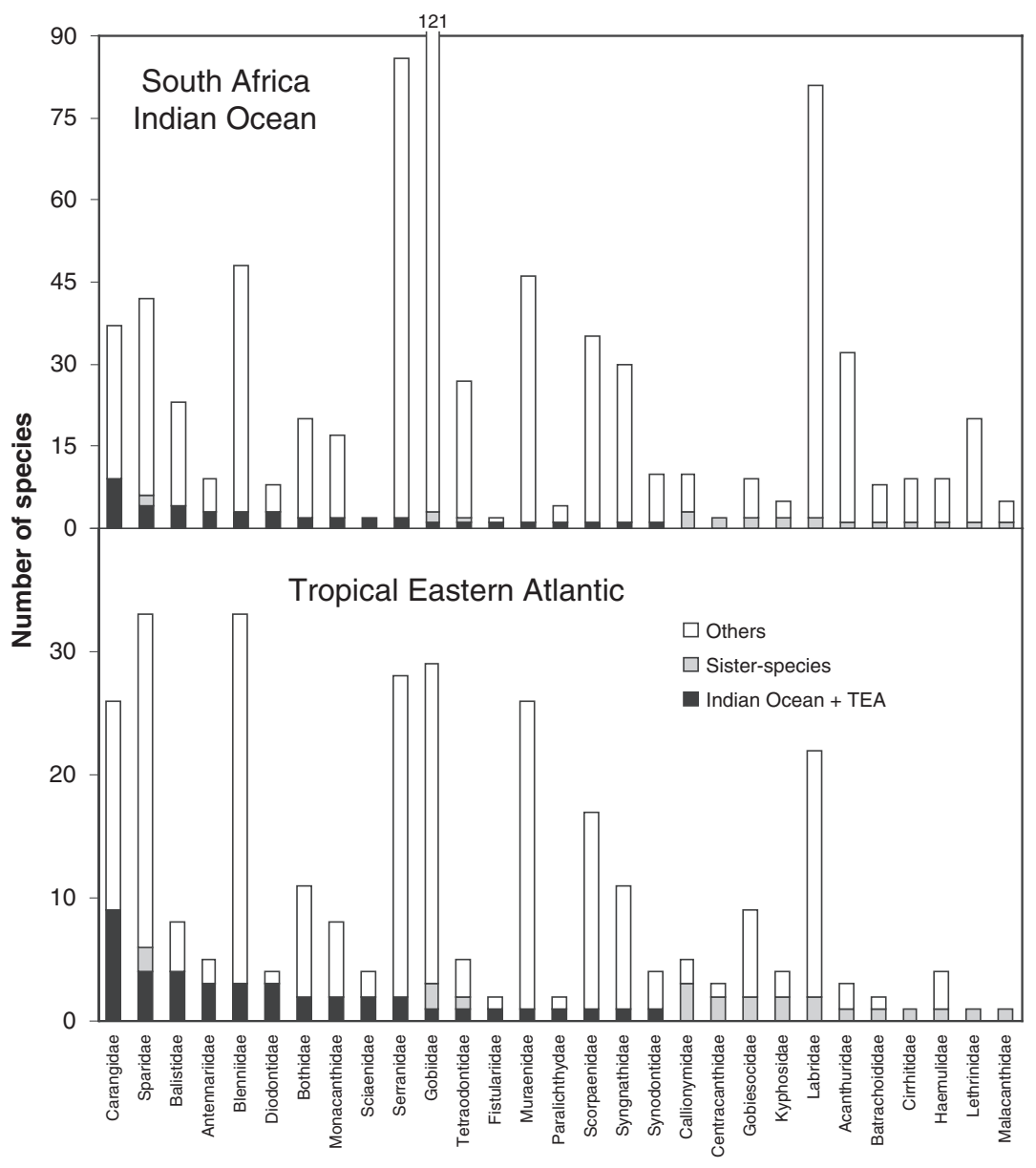

Figure 8 Distributions of species in families of fishes across the Benguela Barrier: numbers of species found on both sides of the barrier (Indian Ocean + Tropical Eastern Atlantic); numbers of species that have their closest relative on the other side of the barrier (sisters); and numbers of species found on one side that have no known sisters on the other side of the barrier (other). biogeographical affinities (i.e. long-branch attraction; Felsenstein, 2004). These areas are a mix of EA and IO species, as expected from their geographic locations. Notwithstanding this, there are a number of endemics in southwestern Africa (38 species representing $12 \%$ of the fauna), such as the genus Clinus with 10 endemic species.

\section{Patterns of historical relationships using phylogenies}

\section{Origins and diversification of Atlantic reef fishes}

Owing to the rarity of reef fish fossils from studied areas (the Mediterranean being the exception; e.g. Carnevale, 2006), historical relationships are recovered from published phylogenetic hypotheses (morphological or molecular-based). Although controversial (cf. Bromham \& Penny, 2003; Pulquério \& Nichols, 2007), molecular phylogenies can provide some idea of the age of cladogenic events through the use of 'molecular clocks' (Avise, 2000). With a collection of 26 available phylogenies involving Atlantic reef fish taxa (references in Methods), we assess the origins and diversification (i.e. faunal enrichment) patterns of Atlantic reef fishes using the evolutionary scenarios shown in Fig. 10. These scenarios are based on the expected timing and sequence of cladogenic events from geological and palaeoceanographic records.
What is the geographical pattern of distributions of sister taxa among provinces?

The three strongest sister-species relationships among regions (Fig. 11) are: (1) the TEA and MAR, with $86 \%$ of the species being sisters (e.g. Thalassoma sanctaehelenae/ascensionis newtoni (Fig. 12), Sparisoma strigatum - cretense); (2) NWA and SWA [78\%; e.g. Thalassoma bifasciatum - noronhanum, Sparisoma griseorubra - frondosum, Diplodus argenteus holbrooki/bermudensis, Halichoeres (Fig. 12), Acanthurus 'bahianus' clades]; and (3) the TEP and NWA [69\%; e.g. Abudefduf taurus - concolor, Anisotremus virginicus - taeniatus (Fig. 13)]. While outside the domain of this study, we also observed strong relationships between the IO and WP [75\%; e.g. Hippocampus ' kuda' complex, Pomacanthus (Fig. 12)].

The relatively recent formation of the Isthmus of Panama is reflected in the number of endemic genera (Fig. 9) and sister taxa shared between the WA and the TEP (e.g. Rosenblatt, 1967; Knowlton \& Weigt, 1998; Bernardi \& Lape, 2005). Many Caribbean reef fishes are phylogenetically related to the EP [69\%; e.g. Abudefduf taurus - concolor, Anisotremus virginicus taeniatus (Fig. 13)]. However, it is important to note that Robertson et al. (2004) reviewed the literature and showed that 10 out of $16 \mathrm{EP}$ species ( 0.63 ratio) are more closely related to Indo-Pacific than to NWA lineages. Thus, the relationship 


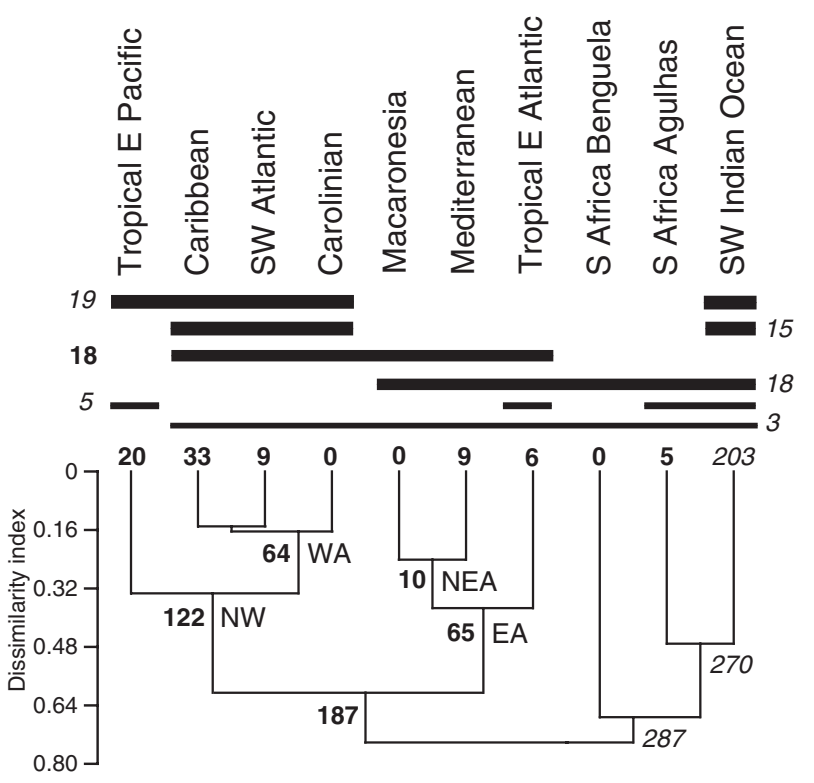

Figure 9 Cluster analysis based on the presence/absence of genera in different areas of the Atlantic and Southern Africa and the number of endemic genera in each area (Bray-Curtis, UPGMA). Horizontal lines show disjunct distributions (or distributions not related to the cluster analysis) of the genera. Numbers opposite the horizontal lines represent the total number of genera related to each distribution. Line thickness is proportional to the number of genera. Bold numbers represent endemism. Italicized numbers do not represent strict endemism, but genera found in the assigned areas plus the IWP. NW: New World; WA: Western Atlantic; NEA: Northeastern Atlantic; EA: Eastern Atlantic. between the EP and the NWA (69\%) is about the same as its relation to the WP (63\%; e.g. Thalassoma lucasanum; Aulostomus). The Caribbean reef fishes are more closely related to the TEP (69\%) than to the EA [47\%; e.g. Hippocampus erectus - hippocampus (Fig. 12)].

The Mid-Atlantic Barrier seems quite permeable, at least in terms of the relationship between Brazil and the Gulf of Guinea. Brazilian species are sisters to EA species in $67 \%$ of the cases [e.g. Clepticus brasiliensis - africanus, Hippocampus reidialgiricus (Fig. 12)]. The percentage of sisters between the Caribbean and the EA is lower (47\% of cases) than the BrazilEA link, and the same pattern applies to the MAR (63\% BrazilMAR and $44 \%$ Caribbean-MAR). It is interesting that Abudefduf taurus is found in the Caribbean and in the TEA, but not in Brazil; however, Muraena melanotis is found in St Paul's Rocks and in the TEA, but not in the Caribbean. Recent records of strays of Sargocentron hastatum in the Caribbean (Wilk et al., 2005) and Acanthurus monroviae in Brazil (Luiz et al., 2004) indicate that this barrier is breached occasionally.

Relationships between the Atlantic reef fish fauna and that of the Indian Ocean are also strong, 67\% of the nodes being sisters in comparisons with the TEA (e.g. Aulostomus chinensis - strigosus (Fig. 12); Lethrinus atlanticus), and 50\% with the Caribbean, Brazil and the MAR [e.g. Dermatolepis inermis striolata, Gnatholepis, Centropyge (Fig. 12)]. Craig \& Hastings (2007) showed that two EA Cephalopholis species (taeniops and nigri) are closely related to species present in the IO, instead of in the WA. Other examples of putative sistership between the IO and the EA are the Anthiinae Meganthias carpenteri (EA) and M. natalensis (IO) (Anderson, 2006), the butterflyfishes (a) Tethys vicariance relicts

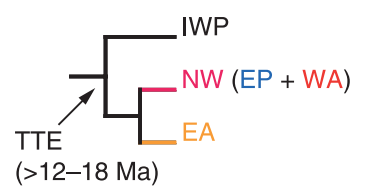

(b) Invasion via the Isthmus prior to closure

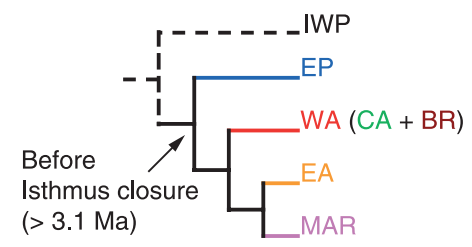

Figure 10 Evolutionary scenarios for Atlantic reef fishes based on expected timing and sequence of cladogenetic events derived from geological and palaeoceanographic records. Colour coding represents geographical areas: magenta, New World (NW); blue, Eastern Pacific (EP); red, Western Atlantic (WA); green, Caribbean (CA); brown, Brazil (BR); orange, Eastern Atlantic (EA); pink, mid-Atlantic Ridge (MAR); black: Indo-West Pacific (IWP) origin or splits of unknown geography. IP, Indo-Pacific; IO, Indian Ocean. Splits resulting from the Amazon Barrier are also responsible for faunal enrichment within the Atlantic Basin (see scenarios discussed in Rocha, 2003). These splits result in trans-Amazon sister species (see Figs 6, $12 \& 14$ for examples). (c1) Recent invasion via South Africa

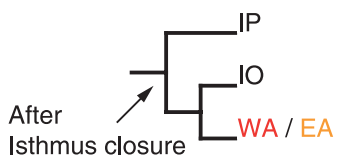
$(<3.1 \mathrm{Ma})$

(c2) Benguela vicariance

(d) New World origin

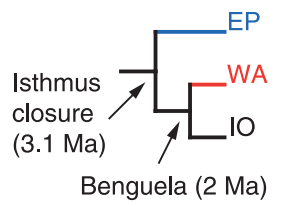

Within the Atlantic Basin

(e) Recent invasion from WA to EA

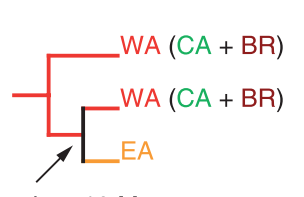

Less than $10 \mathrm{Ma}$

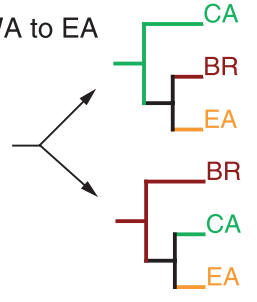

(f) Recent invasion from EA to WA



Less than $10 \mathrm{Ma}$ 


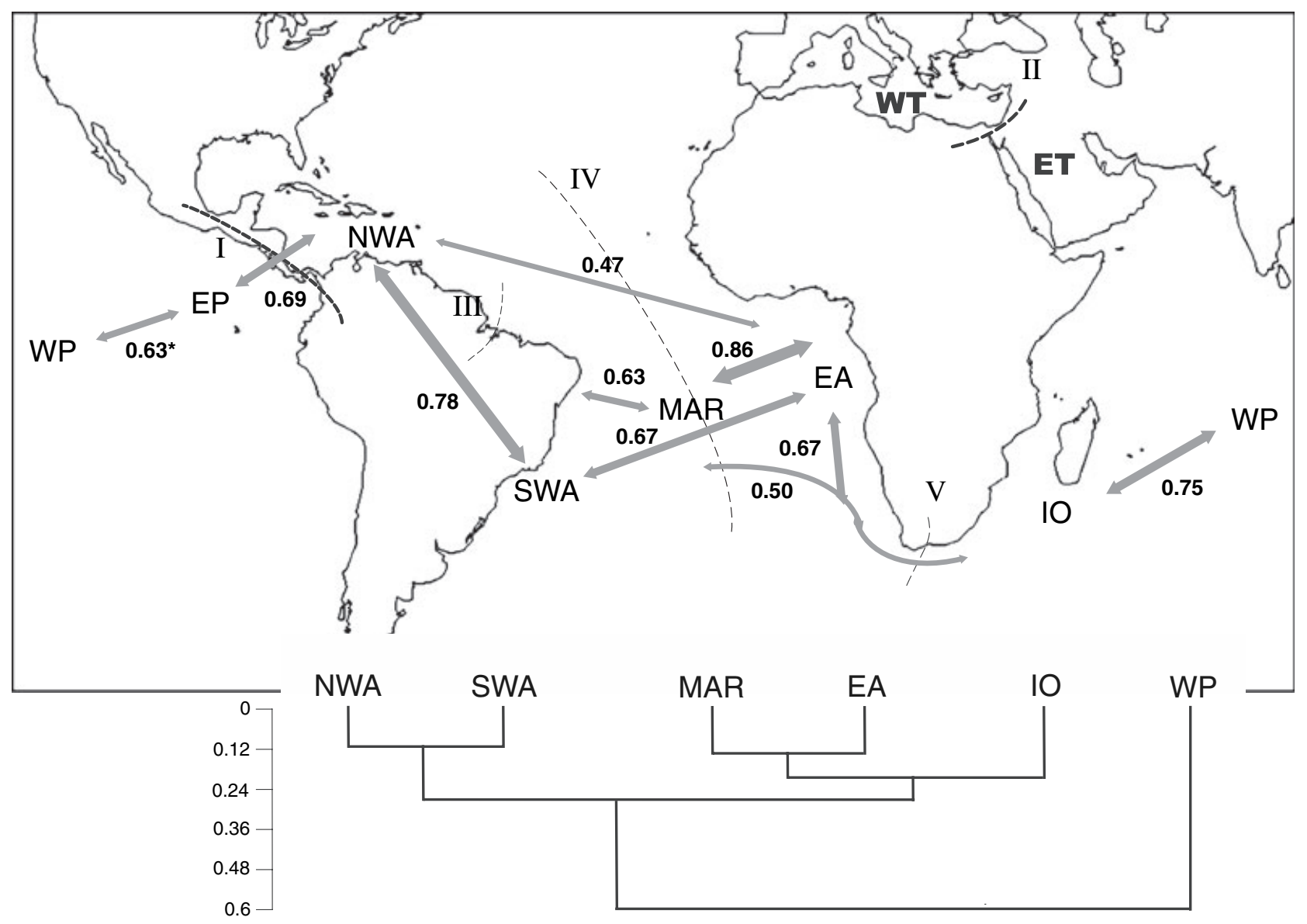

Figure 11 Biogeographical barriers and relationships among areas based on reef fish phylogenies. Legends of the barriers are the same as in Fig. 1. Areas/Provinces: WT, West Tethys; ET, East Tethys. WP, West Pacific; EP, Eastern Pacific; NWA, Northwestern Atlantic (Caribbean + Bermuda + Carolinian); SWA, Southwestern Atlantic (Brazil + Brazilian oceanic islands + Argentina); MAR, Mid-Atlantic Ridge (Ascension + St Helena); EA, Eastern Atlantic (Mediterranean + Macaronesia + Gulf of Guinea + Benguela); IO, Indian Ocean. Arrow width is sized proportionally to the ratio (proportion; numbers are given in each arrow) between the number of nodes in which two areas form a sister pair in a given phylogeny and the number of times the same pair of areas are available for evaluation in the studied phylogenies (see Methods). In order to summarize the relationships among the areas, a cluster analysis (Bray-Curtis; UPGMA) based on the matrix of ratios indicating the importance of the phylogenetic connections is shown at the bottom. Varying the clustering routine has no effect on the grouping of the sites, except for the EP, which was further excluded from the analysis owing to its inconsistent position in the dendrogram with different routines (sometimes grouping with the Western Atlantic sites and sometimes grouping with the Western Pacific). ${ }^{*}$ : ratio based on the compilation of genetic studies by Robertson et al. (2004). The arrows connecting to the IO represent separate numbers for the EA-IO and WA-IO relationships.

Chaetodon hoefleri (EA) and C. marleyi (IO), and the Drepanidae Drepane africana (EA) and D. longimana (IO) (Heemstra \& Heemstra, 2004). All these cases indicate a clear phylogenetic connection of the TEA to (sub)tropical southern Africa.

Another interesting aspect among sister species is the percentage of putative sympatric (or microallopatric) vs. allopatric speciation. From a total of 50 sister pairs in the available phylogenies we found only nine examples $(18 \%)$ of range overlap (i.e. where sympatric speciation might be inferred). Williams \& Reid (2004) reported five examples of range overlap between sister species among 19 studied pairs in snails of the genus Echinolittorina. Among these cases, we could not be sure that sympatric speciation occurred because they could also reflect secondary contact after allopatric split, and thus although sympatric speciation may have occurred it seems to be of less importance in marine faunal enrichment.

Are phylogenetic and distributional patterns concordant with 'traditionally' accepted provinces?

The overall picture is that phylogenetic and distributional patterns are concordant. In spite of the Amazon filter (Floeter \& Gasparini, 2000; Joyeux et al., 2001; Rocha, 2003), a strong relationship between the NWA and the SWA exists in terms of both shared species (Fig. 5) and sister species (Figs 6 \& 11). It is interesting to note that many 'Brazilian' fishes were recently discovered in the southern tip of the Caribbean (e.g. St. Vincent, Venezuela and Tobago; see Joyeux et al., 2001; Rocha, 2003; Robertson et al., 2006). New genetic evidence has also 
Figure 12 Phylogenies related to Tethys relicts, recent invasions from the Indian Ocean, and diversification within the Atlantic scenarios. Colour coding represents geographic ranges: blue, Eastern Pacific (EP); red, Western Atlantic (WA); green, Caribbean (CA); brown, Brazil (BR); orange, Eastern Atlantic (EA); pink, mid-Atlantic Ridge (MAR); black, IWP origin or splits of unknown geography. Numbers (or confidence intervals) represent the estimated timing of speciation events in $\mathrm{Ma}$ as given in the original publications. The minimum age of 3.1 Ma for the splits related to the final closure of the Isthmus of Panama is assumed. Age estimates for Pomacanthidae were calibrated using fossil evidence (see Bellwood et al., 2004). Coalescence analysis was used to estimate divergence times in Centropyge and Gnatholepis (Rocha et al., 2005a; Bowen et al., 2006a). The complete phylogeny for the genus Sparisoma is given in Fig. 14.
Figure 13 Phylogenies related to the origin in the New World scenario. See Fig. 12 legend for colour codes and inferred timing of speciation events.

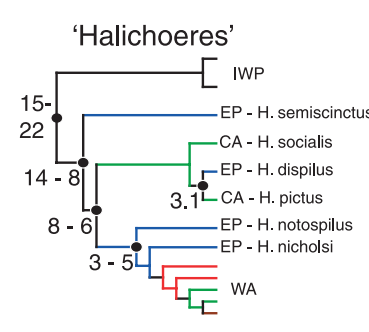

\section{Tethys vicariance}
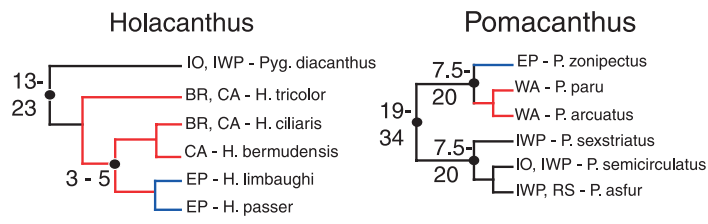

Recent invasions via South Africa

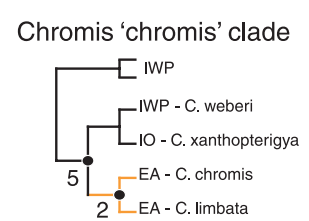

Dermatolepis

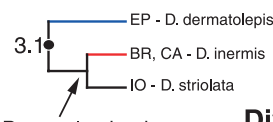

Benguela vicariance

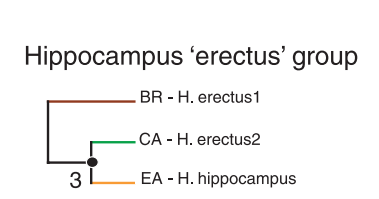

\section{Ophioblennius}
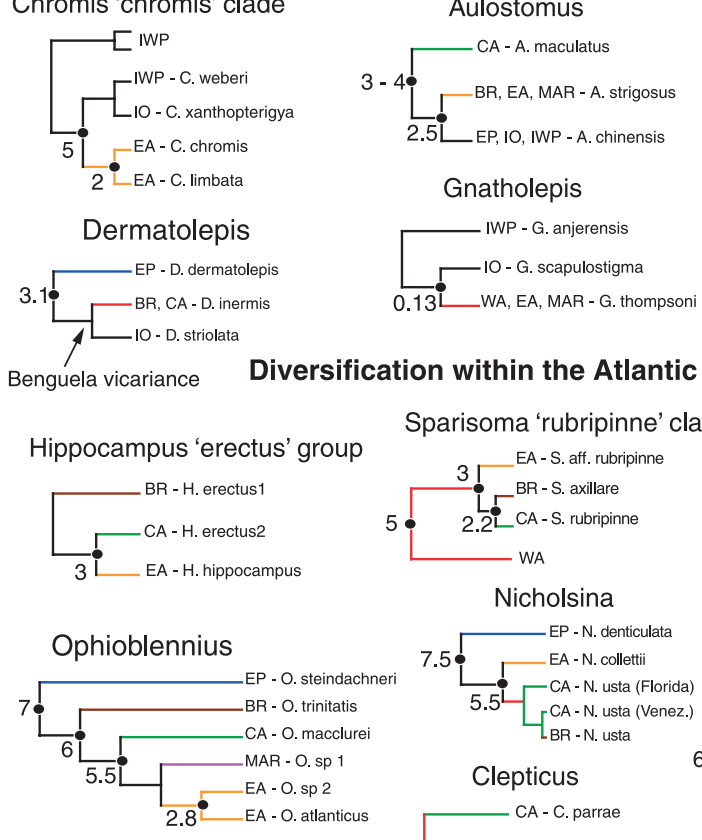

Diversification within the Atlantic basin
Centropyge

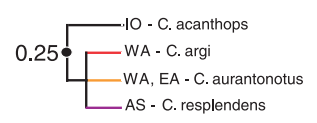

Hippocampus 'kuda complex'

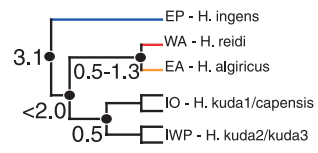

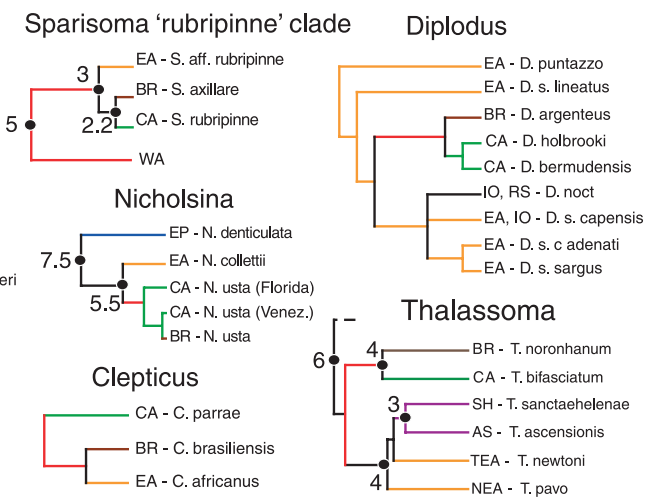

\section{Alphestes}

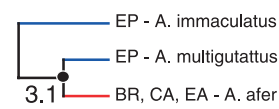

Stathmonotus

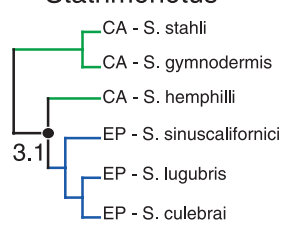

Gobiesocinae

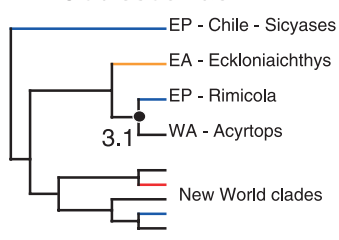

\section{New world origin}

Elacatinus

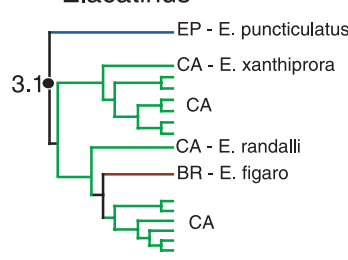

Anisotremus



Chromis 'cyanea' clade

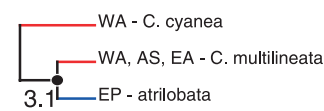

Elacatinus/Risor

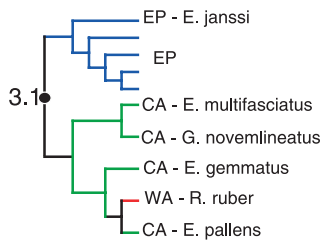

Rypticus

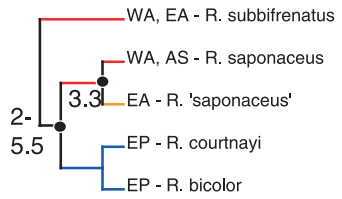

Abudefduf 'declivifrons' clade

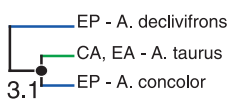

revealed examples of closer evolutionary links between 'Brazilian' and Venezuelan fishes rather than between Brazil and other areas of the NWA [e.g. Sparisoma griseorubra frondosum (Robertson et al., 2006); samples of Nicholsina usta (Brazil) closer to Venezuela than to Florida (Fig. 12)].
The link between the EA and MAR is found both in phylogenetic and in distributional patterns (Figs 5 \& 11). The links between the WA and EA and between the Atlantic basin and Indian Ocean are also concordant. It was not possible to assess the relationships between the TEP and the Atlantic by 
species distributions (they share only a few species), but the relationships at the genus level (Fig. 9) and sister-species numbers reflect this historical connection (e.g. Rosenblatt, 1967; Knowlton \& Weigt, 1998; Fig. 13).

A general agreement with the biogeographical provinces described by Briggs $(1974,1995)$ was observed in all analyses. Both the maximum-parsimony (Fig. 4) and the distance (Figs 5 \& 10) analysis largely agreed with earlier proposed provinces (Briggs, 1974, 1995; Vermeij, 1978). The relationship of the Brazilian oceanic islands with the Brazilian Province also supported Briggs (1974, 1995), Lubbock \& Edwards (1981), Gasparini \& Floeter (2001), Rocha (2003) and Feitoza et al. (2003) in that these islands are impoverished outposts of the Brazilian Province. However, the Brazilian Province should be extended to Santa Catarina at $28^{\circ} \mathrm{S}$ (Floeter et al., 2001).

Briggs (1974) divided the Greater Caribbean into the western Caribbean plus Florida (Caribbean Province) and the eastern Caribbean (West Indian Province). Recent genetic and biogeographical surveys have demonstrated an important partition at the Mona Passage - between Puerto Rico and Hispaniola (Baums et al., 2005; Dennis et al., 2005; Taylor \& Hellberg, 2006), while others found genetic breaks between Florida and the Bahamas (Carlin et al., 2003; Rocha et al., 2005b). Vermeij (2005), working with fossils, also found a deep split between Florida and the Caribbean for molluscs. There is thus some justification for partitioning within the NWA (e.g. Gilbert, 1972). However, genetic analyses of wide-ranging fish species in the NWA revealed no significant partitions in most cases (Shulman \& Bermingham, 1995; Muss et al., 2001; Rocha et al., 2002; Bowen et al., 2006b). Using the 10\% endemism level proposed by Briggs (1974) as well as similarity and parsimony analyses (Figs 4 \& 5), the recognition of a 'Greater Caribbean' Province including the eastern and western Caribbean plus Florida and Bermuda is supported (Burgess et al., 1994; Smith-Vaniz et al., 1999).

As expected, the mid-Atlantic islands of Ascension and St Helena are intermediate in faunal composition between the WA and EA, consistent with their intermediate location. Seventy-one species are shared with the west and 64 with the east, but, as a result of the greater similarity of their total richness with the EA (7.5\% of the WA fauna vs. $16 \%$ for the EA), they clustered with the EA in Figs 5 \& 11 and with southwest Africa and the EA in Fig. 4. A reinforcement of this pattern is the stronger phylogenetic relationship of Ascension and St Helena and the EA [Fig. 11; e.g. Ophioblennius and Thalassoma (Fig. 13)]. However, genetic analyses of the genera Acanthurus and Centropyge in the Atlantic support a close relationship between the MAR and the SWA (Rocha et al., 2002; Bowen et al., 2006a).

The division of the EA into three sub-areas (the TEA, the warm-temperate NEA, and southwestern Africa - Fig. 4) was predicted by sea-surface-temperature isotherm bunching at capes along the African coast. The difference between our analysis and that of Briggs (1974, 1995; i.e. 'Lusitania' Province) is that the northwest African coast is more closely related to the TEA in overall diversity than to the Macaronesian Islands or the Mediterranean. In an analysis of the blenniid fauna, Almada et al. (2001) found that Mauritania clustered with the TEA, but Morocco grouped with the NEA. Ávila (2000) found that Moroccan molluscs were affiliated with both the Cape Verde Islands and the NEA. In addition, there is recent genetic evidence for both endemism in the Mediterranean (e.g. Aurelle et al., 2003; Bargelloni et al., 2003; Table 3) and genetic continuity along the Mediterranean and the Atlantic coastline (e.g. Bargelloni et al., 2003; Costagliola et al., 2004), as well as cases where one of two sister species are present in the Mediterranean and adjacent Atlantic, while the other is found in tropical west Africa and the Macaronesian islands (e.g. Chromis chromis - limbata, Domingues et al., 2005; Parablennius sanguinolentus - parvicornis, Almada et al., 2005).

Is there a general relationship between diversity and origin of clades?

The uneven distribution of species in selected genera in different provinces (Fig. 3) seems to be related to their putative origin. For example, the genera Anisotremus, Elacatinus, Rypticus, Serranus, and Sparisoma all have several species in the NW (New World, i.e. both sides of tropical America) and are now thought to have originated and diversified in the NW (Fig. 13; Guimarães, 1999; Bernardi \& Lape, 2005; Taylor \& Hellberg, 2005; Robertson et al., 2006), some with subsequent invasion of the EA (Fig. 13; Carlin et al., 2003; Serranus - M. Kochzius \& A. Dominici-Arosemena, personal communication). In contrast, the genus Diplodus is more speciose in the EA than in the WA, and its molecular phylogeny indicates an EA origin (Fig. 12; Summerer et al., 2001). Distributional data indicate that the same pattern should be expected for Parablennius and Scartella. (Both lack molecular phylogenies; however, these groups are currently being analysed by V. Almada and collaborators.)

The link between species richness and area of origin is found in the genus Lethrinus, which occurs in the EA and the Indo-Pacific but not in the WA. The only Atlantic species (L. atlanticus) is nested deeply within the Indo-Pacific Lethrinus (Galbo et al., 2002), indicating that this genus originated and diversified in the Indo-Pacific, and that the Atlantic species is the result of an invasion around 5-6 Ma, assuming the standard divergence of $2 \%$ per million years for cytochrome b (Avise, 2000). Even considering a divergence rate of $1 \%$ per million years, this invasion probably occurred via southern Africa well after the Tethyan Terminal Event (c.12-18 Ma).

In summary, it seems that the greatest species richness for reef fish genera is found at their locations of origin.

Is there a congruent pattern linked to historical events? Is the timing of divergence consistent among the various taxa?

It is clear from the phylogenies that all major biogeographical barriers/filters left their marks (Figs 12-14). Nevertheless, 
Figure 14 Comparative chronogram of cladogenic events based on seven distinct reef fish phylogenies (references in Methods). Time-scales are based on conventional rates of divergence for fish cytochrome $\mathrm{b}$ sequences ( $1 \%$ per $\mathrm{Ma}$ at the top and $2.5 \%$ per Ma at the bottom). The grey band highlights the diversification that occurred during the late Miocene to the Pliocene (peaking from 8 to $2 \mathrm{Ma}$ if the $2.5 \%$ per $\mathrm{Ma}$ time-scale is assumed). Colour coding represents geographic ranges as in Figs 12 and 13.

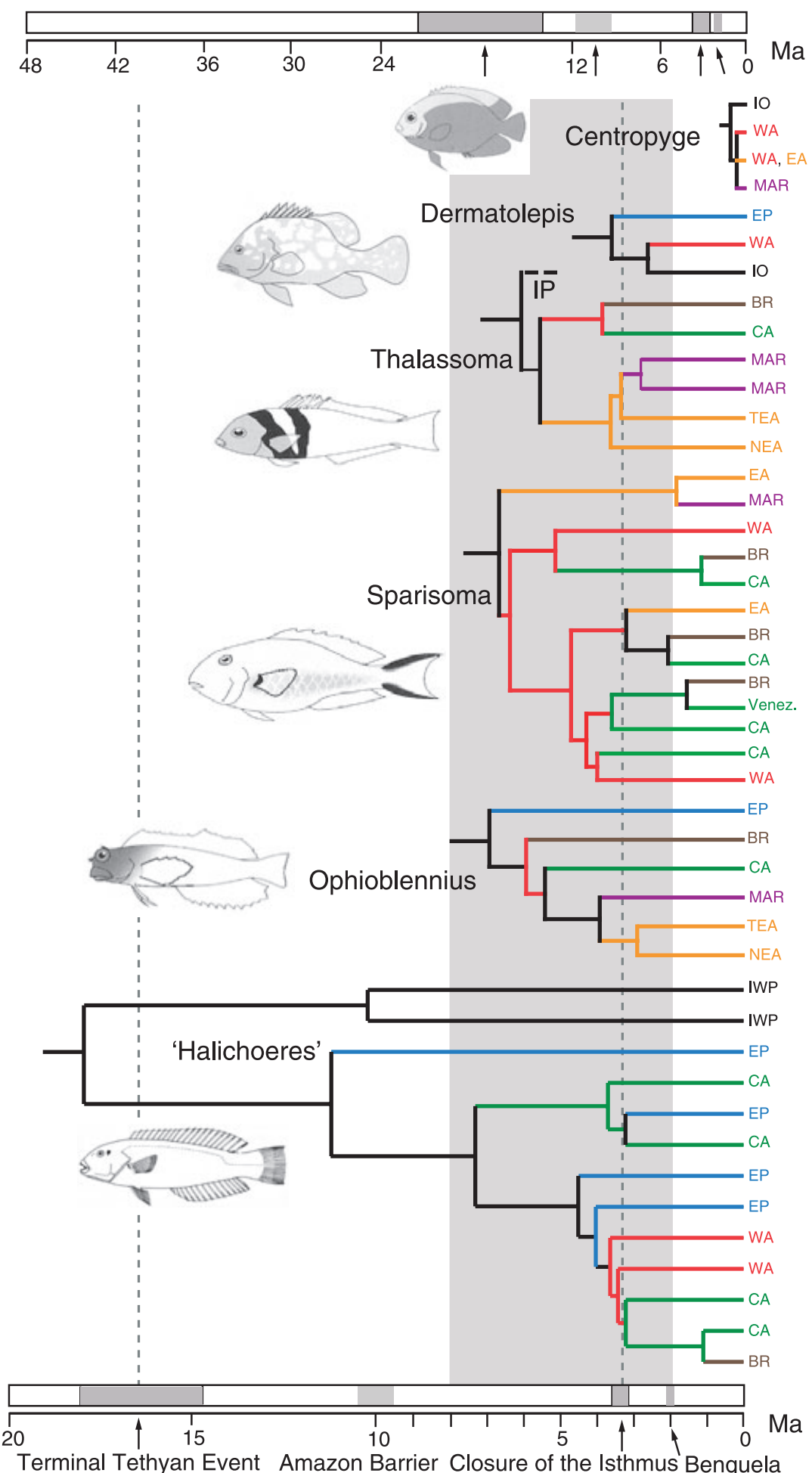

Terminal Tethyan Event Amazon Barrier Closure of the Isthmus Benguela speciation events are not simply predicted by geological or oceanographic events. Both episodic extinction and cladogenic events influence patterns of faunal richness. Owing to the lack of a fossil record for reef fishes, we could not infer extinctions; instead, we could only explore relationships between speciation and large-scale historical events.
The timing of cladogenic events is not concordant among genera (Figs 12 \& 13). For example, trans-Atlantic divergence times range from c. $5.5 \mathrm{Ma}$ (Fig. 13; Thalassoma, Costagliola et al., 2004; Nicholsina usta clade, Robertson et al., 2006) to c. $3 \mathrm{Ma}$ (Fig. 13; Sparisoma 'rubripinne' clade, Robertson et al., 2006; Hippocampus 'erectus' clade, Casey et al., 2004), as well as $\leq 1 \mathrm{Ma}$ (Fig. 13; Hippocampus reidi - algiricus, Casey et al., 
2004) to a few tens of thousands of years (Gnatholepis, Rocha et al., 2005a). The relatively recent time frame of partitions (e.g. Robertson et al., 2006) eliminates vicariance following the opening the Atlantic (65 Ma), and there is no suggestion of simultaneous interruptions of gene flow among species resulting from a single palaeoceanographic event.

The lack of congruent divergences is also found across the Amazon barrier [Figs 13 \& 14: from $6 \mathrm{Ma}$ in Ophioblennius macclurei - trindadensis (Muss et al., 2001); to $4 \mathrm{Ma}$ in Thalassoma bifasciatum - noronhanum (Costagliola et al., 2004); to c. $1 \mathrm{Ma}$ in Acanthurus bahianus (Rocha et al., 2002), Halichoeres radiatus - brasiliensis (Rocha, 2004) and Sparisoma atomarium - tuiupiranga (Robertson et al., 2006); to very recent in Acanthurus coeruleus (Rocha et al., 2002) and Sparisoma viride - amplum (Robertson et al., 2006)]. Likewise, the dispersal events from the Indian Ocean to the Atlantic vary widely through time (Fig. 13; from 4.6 Ma in the Chromis 'chromis' clade to $0.13 \mathrm{Ma}$ in Gnatholepis, Rocha et al., 2005a). These invasions seem to have occurred both before the Benguela upwelling c. $2 \mathrm{Ma}$ and relatively recently (Bowen et al., 2001, 2006a; Rocha et al., 2005a).

In summary, the Benguela, mid-Atlantic, and Amazon filters have restricted dispersal but also allowed occasional crossings that resulted in the establishment of new populations and species. Ocean-current dynamics, which are likely to affect dispersal across these barriers, have varied considerably with changing sea-levels over the past 10 Myr (Kaneps, 1979; Rocha, 2003; Robertson et al., 2006). The effectiveness of the Amazon barrier, in particular, is thought to have been strongly influenced by changing sea-levels not only through variation in current speeds (Kaneps, 1979), which affect larval transit times, but also through variations in the salinity of that barrier and the availability of marine habitats beneath the freshwater plume (Rocha, 2003). Fluctuations in the effectiveness of the three filters provide a mechanism for much of the recent diversification of reef fishes in the Atlantic.

Despite the lack of a consistent temporal signal for speciation events, an important diversification occurred during the late Miocene to the Pliocene (peaking from 8 to $2 \mathrm{Ma}$; Fig. 14). This phenomenon is probably related to the closing of the Isthmus of Panama and its effects on the direction and speed of the Atlantic currents (see Muss et al., 2001 and references therein). A second burst of speciation events occurred well after the Isthmus closure (Figs 13 \& 14), many of them $\leq 1.5 \mathrm{Ma}$ and possibly related to fluctuations in the effectiveness of the three filters or recent diversification across ecological gradients (Rocha, 2004; Rocha et al., 2005a,b; Taylor \& Hellberg, 2005; Robertson et al., 2006). For example, some Caribbean species are present in the Brazilian offshore islands of Fernando de Noronha and Atol das Rocas (South of the Amazon barrier) but do not occur on the adjacent Brazilian continental shoreline, which imposes very different ecological conditions (high sediment loads, low water transparence, continental freshwater runoff, etc.). In some cases, these species are replaced by closely related sister taxa along the coast. This observation led Rocha et al. (2005b) to propose ecological speciation in the genus Halichoeres, and a very similar pattern was observed in gobies of the genus Bathygobius (Lima et al., 2005).

What is the relative importance of vicariant persistence and dispersal routes on contemporary biodiversity?

Our data indicate that both vicariant events, such as the closure of the Isthmus of Panama, and dispersal events across the three primary Atlantic biogeographical filters have contributed to the distribution patterns that we observe today.

Theories concerning the origins of the NW reef biota involve two primary hypotheses: relicts of Tethyan fauna vs. colonization from the IWP (Veron, 1995; Barber \& Bellwood, 2005). The relict hypothesis is based on the separation of the western Atlantic from the eastern Indian and Pacific oceans, resulting in two isolated reef systems after the final closure of the Red Sea land bridge c. 12-18 Ma (Steininger \& Rögl, 1984). The alternative hypothesis is colonization from the Pacific across the East Pacific Barrier (EPB) and into the Caribbean prior to the closure of the Isthmus of Panama, and/or colonization of the Atlantic from the Indian Ocean via southern Africa.

These theories yield clear predictions. The relict theory predicts that the age of the Atlantic/East Pacific fauna must exceed $12 \mathrm{Myr}$, with origins derived from IO lineages (Fig. 10, scenario A). Colonization via the opened Isthmus predicts that NW species must be older than 3.1 Myr (Coates \& Obando, 1996), and that they will have sister taxa with central and eastern Pacific distributions (Fig. 10, scenario B). Recent invasions via South Africa predict that Atlantic species must be younger than 3.1 Myr and will have Indian Ocean sister species (Fig. 10, scenario C1). A vicariant scenario (C2) involving the closure of the Isthmus of Panama and the intensification of the Benguela upwelling system could involve the following steps: (1) an original large geographical range encompassing the IO, WA and TEP; (2) isolation of the TEP population with the rise of the Isthmus (c. 3.1 Ma); and (3) isolation of the WA and the IO by the Benguela Barrier ( $c$. $2 \mathrm{Ma})$.

Other possible scenarios for the origins and diversification of the Atlantic reef fauna would be origin in the NW, probably after W-E Tethys separation deep in the phylogenies - i.e. 'sister-genera' relationships (Fig. 10, scenario D), and/or dispersal within the Atlantic basin (Fig. 10, scenarios $\mathrm{E}$ and $\mathrm{F})$.

From our compilation of phylogenies (Figs 12-14), Atlantic reef fishes fit all of the proposed scenarios. Supporting the Tethys relict scenario, we have examples of the 18-Ma major split in the Halichoeres phylogeny (Figs 12 \& 14), and the c. 20-Ma splits in Holacanthus and Pomacanthus, all dividing the NW and IWP clades. Moreover, there is the morphological phylogeny of Scaridae (Bellwood, 1994), where Sparisoma is thought to be a Tethyan relict (Streelman et al., 2002). A similar case is the 20-Ma split of the EA clade Chaetodon robustus-hoefleri (Chaetodontidae) from IWP clades (Fessler \& 
Westneat, 2007). Orrell et al. (2002) also suggested a clear Tethyan partition within the sparid evolution.

Supporting colonization via the opened Isthmus hypothesis (Fig. 10, scenario B), we have the diversification of a NWA clade within Halichoeres (Barber \& Bellwood, 2005) and Thalassoma (Costagliola et al., 2004) (Fig. 14). Bellwood (1994) and Gomon (1997) discuss similar cases for Scarus and Bodianus, respectively.

In recent years, there has been mounting evidence that late Pliocene or Pleistocene ( $<3 \mathrm{Ma}$ ) invasions via southern Africa (Fig. 10, scenario C1) contribute to diversity in the Atlantic. Examples in Fig. 12 include the genera Aulostomus, Centropyge, Gnatholepis, and the Hippocampus ' $k u d a$ ' clade (see Casey et al., 2004; Rocha et al., 2005a; Bowen et al., 2006a). The evolution of the genus Dermatolepis fits with scenario C2.

Relatively recent diversification within the NW (Fig. 10, scenario D - with or without ancient separation of clades related to Tethys) is found in the Abudefduf 'declivifrons' clade, Alphestes, Anisotremus, Chaenopsidae, Chromis 'cyanea' clade, Elacatinus, Gobiescocinae, and Rypticus. It is interesting to note that the number of geminate pairs separated by the Isthmus of Panama is relatively low, compared with the total number of species in the Neotropical clades. Speciation events within the EP or the WA are much more common than previously expected, and may correspond to instances of sympatric and ecological speciation.

Within the Atlantic basin, the available phylogenies indicate invasions from the WA to the EA in most cases: Clepticus, Hippocampus 'erectus' clade, Nicholsina, Ophioblennius, Sparisoma 'rubripinne' clade, and Thalassoma (Fig. 10, scenario E). Invasions from the EA to the WA are rare (e.g. Diplodus). However, further studies of other genera with distribution patterns like that of the genus Parablennius (see Fig. 3) may reveal more cases of westward migrants (see Luiz et al., 2004; Fig. 10, scenario F).

In summary, historical relationships among Atlantic provinces are complex and reticulated (sensu Brooks, 2004), with provinces comprising a mixture of residents (species that evolved within province boundaries - after the closure of the Tethys seaway) and colonizers (species that evolved outside the province and dispersed across a variety of time frames). Moreover, this work provides additional evidence for the importance of founder speciation by means of dispersal in the evolution of reef fishes (see also Paulay \& Meyer, 2002 and Queiroz, 2005).

\section{Conclusions and future prospects}

Here we have attempted to elucidate the role of biogeographical hard barriers (Tethys and Panama) as well as of more porous biogeographical filters (Benguela, mid-Atlantic, and Amazon barriers) in generating and maintaining Atlantic biodiversity. Most of the contemporary reef fish families were established by the lower Eocene (50 Ma), and most modern genera were present by the mid-Miocene (10 Ma) (Bellwood \& Wainwright, 2002). As a consequence, the closure of the Tethys
Sea must have affected the evolution of Atlantic reef biota. Some elements of the Atlantic reef fauna pre-date this event, including corals (Veron, 1995), the endemic lineages of parrotfishes (Bellwood, 1994; Streelman et al., 2002), some wrasses (Barber \& Bellwood, 2005), and angelfishes (Bellwood et al., 2004). The three soft barriers or filters have clearly restricted dispersal and have promoted the development of new species in allopatry and/or parapatry. Since habitat characteristics vary greatly among regions, ecological speciation may also have been important in diversification. Fluctuations in the effectiveness of the soft barriers provide a mechanism for much of the recent faunal exchanges in the Atlantic. Thus, vicariant events (e.g. the closure of the Isthmus of Panama), relatively recent dispersal (with further speciation or not), and adaptation to novel habitats seem to have combined to regulate Atlantic tropical marine biodiversity, all having contributed to the biogeographical patterns we observe today. Processes originating from dispersal across barriers or colonization of novel habitats seem to outnumber vicariant events. However, it will be necessary to analyse additional higher-level phylogenies (family and genus levels; e.g. Orrell et al., 2002), when they become available, to separate out the relative importance of Tethys relicts vs. later colonization. The plurality of biogeographical histories and speciation patterns in the marine tropics found here agrees with the recent findings of Rocha (2003) for fishes, Meyer (2003) for cowries, and Williams \& Reid (2004) for littorinid snails.

Finally, there are undeniable roles for humanity in contemporary biogeographical processes. These include three obvious factors involving the transport and introduction of exotic species, and probably several others that elude our grasp. First, the aquarium trade has introduced Indo-Pacific species into the Atlantic, most notably the Pacific lionfishes in the NWA (Whitfield et al., 2002). Second, ballast water in cargo vessels is considered a primary threat; however, the screens on ballast tanks mostly exclude fish larvae, and the smaller invertebrate larvae are a much greater hazard (Wonham et al., 2000). Third, the Suez Canal has essentially reopened the Tethys Sea connection between the Red Sea and the Mediterranean. The invasions to date have been for the most part limited by the cooler subtropical conditions in the Mediterranean [but see Edwards (1987) for examples of some species that have spread their distribution ranges since 1902 and Bariche \& Saad (2005) for a recent example], but this may change if predictions of global warming are accurate (see Brito et al., 2005 and Bianchi, 2007 on the recent tropicalization of the littoral ichthyofauna of the Canary Islands and the Mediterranean). Both the Suez connection and the southern African connection may be enhanced by global warming, and the consequences for interocean faunal exchanges are uncertain.

\section{ACKNOWLEDGEMENTS}

We thank the following people for helping us cross-check data, allowing us to use unpublished data, and/or sharing their expert knowledge in their study families: L. Beckley, 
P.A. Hulley, P.H. Skelton, D. Polack, J.L. Van Tassell, J. Leis, R. Fricke, J.E. Randall, W.N. Eschmeyer, G.R. Allen, P. Lobel, M. Biscoito, A.G. Floeter, R. Reeves, O.J. Luiz Jr, J.C. Briggs, R.R. Warner, A. Carvalho-Filho, J. Williams and K. Matsuura. We also thank colleagues who reviewed earlier versions of the manuscript: G.J. Vermeij, J.C. Briggs, V. Faria, V. Almada, V. Domingues and H. Choat. Essential financial support was provided by the Smithsonian Tropical Research Institute (STV grants to S.R.F. and C.E.L.F.), the National Geographic Society (grants 7937-05 to S.R.F. and 7708-04 to L.A.R.), and the Universidade Federal de Santa Catarina. This work was partly conducted while S.R.F. was a postdoctoral associate at the National Center for Ecological Analysis and Synthesis, a center funded by the NSF (grant DEB-0072909) and the University of California, Santa Barbara. We also acknowledge the access to many institutional ichthyological collections and the cooperation of their curatorial staffs without their help the distributional data for this study would have been inadequate.

\section{REFERENCES}

Afonso, P., Porteiro, F.M., Santos, R.S., Barreiros, J.P., Worms, J. \& Wirtz, P. (1999) Coastal marine fishes of São Tome Island (Gulf of Guinea). Arquipélago Life and Marine Sciences, 17A, 65-92.

Allen, G.R. \& Adrim, M. (2003) Coral reef fishes of Indonesia. Zoological Studies, 42, 1-72.

Almada, V.C., Oliveira, R.F., Gonçalves, E.J., Almeida, A.J., Santos, R.S. \& Wirtz, P. (2001) Patterns of diversity of the north-eastern Atlantic blenniid fish fauna (Pisces: Blenniidae). Global Ecology and Biogeography, 10, 411-422.

Almada, F., Almada, V.C., Domingues, V.S., Brito, A. \& Santos, R.S. (2005) Molecular validation of the specific status of Parablennius sanguinolentus and Parablennius parvicornis (Pisces: Blenniidae). Scientia Marina, 69, 519-523.

Anderson, W.D., Jr (2006) Meganthias carpenteri, new species of fish from the eastern Atlantic Ocean, with a key to eastern Atlantic Anthiinae (Perciformes: Serranidae). Proceedings of the Biological Society of Washington, 119, 404-417.

Aurelle, D., Guillemaud, T., Afonso, P., Morato, T., Wirtz, P., Santos, R.S. \& Cancela, M.L. (2003) Genetic study of Coris julis (Osteichtyes, Perciformes, Labridae) evolutionary history and dispersal abilities. Comptes Rendus Biologies, 326, 771-785.

Ávila, S.P. (2000) Shallow-water marine mollusks of the Azores: biogeographical relationships. Arquipélago Life and Marine Sciences, 2A, 99-131.

Avise, J.C. (2000) Phylogeography: the history and formation of species. Harvard University Press, Cambridge, MA.

Banford, H.M., Bermingham, E. \& Collette, B.B. (2004) Molecular phylogenetics and biogeography of transisthmian and amphi-Atlantic needlefishes (Belonidae: Strongylura and Tylosurus): perspectives on New World marine speciation. Molecular Phylogenetics and Evolution, 31, 833851.
Barber, P.H. \& Bellwood, D.R. (2005) Biodiversity hotspots: evolutionary origins of biodiversity in wrasses (Halichoeres: Labridae) in the Indo-Pacific and New World tropics. Molecular Phylogenetics and Evolution, 35, 235-253.

Bargelloni, L., Alarcorn, J.A., Alvarez, M.C., Penzo, E., Magoulas, A., Reis, C. \& Patarnello, T. (2003) Discord in the family Sparidae (Teleostei): divergent phylogeographical patterns across the Atlantic-Mediterranean divide. Journal of Evolutionary Biology, 16, 1149-1158.

Bariche, M. \& Saad, M. (2005) Settlement of the lessepsian blue-barred parrotfish Scarus ghobban (Teleostei: Scaridae) in the eastern Mediterranean. Journal of the Marine Biological Association UK.2, Biodiversity Records Ref. No. 5049, 1-3.

Baums, I.B., Miller, M.W. \& Hellberg, M.E. (2005) Regionally isolated populations of an imperiled Caribbean coral, Acropora palmata. Molecular Ecology, 14, 1377-1390.

Bellwood, D.R. (1994) A phylogenetic study of the parrotfishes family Scaridae (Pisces: Labroidei), with a revision of genera. Records of the Australian Museum, Supplement, 20, 1-86.

Bellwood, D.R. \& Wainwright, P.C. (2002) The history and biogeography of fishes on coral reefs. Coral reef fishes. Dynamics and diversity on a complex ecosystem (ed. by P.F. Sale), pp. 5-32. Academic Press, New York, NY.

Bellwood, D.R., van Herwerden, L. \& Konow, N. (2004) Evolution and biogeography of marine angelfishes (Pisces: Pomacanthidae). Molecular Phylogenetics and Evolution, 33, 140-155.

Bernardi, G. \& Lape, J. (2005) Tempo and mode of speciation in the Baja California disjunct fish species Anisotremus davidsonii. Molecular Ecology, 14, 4085-4096.

Bianchi, C.N. (2007) Biodiversity issues for the forthcoming tropical Mediterranean Sea. Hydrobiologia, 580, 7-21.

Böhlke, J.E. \& Chaplin, C.C.G. (1993) Fishes of the Bahamas and adjacent tropical waters. University of Texas Press, Austin, TX.

Bowen, B.W., Bass, A.L., Rocha, L.A., Grant, W.S. \& Robertson, D.R. (2001) Phylogeography of the trumpetfish (Aulostomus): ring species complex on a global scale? Evolution, 55, 1029-1039.

Bowen, B.W., Muss, A.J., Rocha, L.A. \& Grant, W.S. (2006a) Shallow mtDNA coalescence in Atlantic pygmy angelfish (genus Centropyge) indicates a recent invasion from the Indian Ocean. Journal of Heredity, 97, 1-12.

Bowen, B.W., Bass, A.L., Muss, A.J., Carlin, J. \& Robertson, D.R. (2006b) Phylogeography of two Atlantic squirrelfishes (family Holocentridae): exploring pelagic larval duration and population connectivity. Marine Biology, 149, 899913.

Briggs, J.C. (1955) A monograph of the clingfishes (Order Xenopterygii). Stanford Ichthyological Bulletin, 6, 1-224.

Briggs, J.C. (1966) Oceanic islands, endemism, and marine paleotemperatures. Systematic Zoology, 15, 153-163.

Briggs, J.C. (1973) Operation of zoogeographic barriers. Systematic Zoology, 23, 248-256.

Briggs, J.C. (1974) Marine zoogeography. McGraw-Hill, New York. 
Briggs, J.C. (1995) Global biogeography. Developments in paleontology and stratigraphy, 14, Elsevier, Amsterdam.

Brito, A., Herrera, R., Falcón, J.M., García-Charton, J.A., Barquín, J. \& Pérez-Ruzafa, A. (1999) Contribución al conocimiento de la ictiofauna de las islas de Cabo Verde. Revista de la Academia Canaria de Ciencias, 11, 27-41.

Brito, A., Pascual, P.J., Falcon, J.M., Sancho, A. \& Gonzalez, A. (2002) Peces de las Islas Canarias. Francisco Lemus Editor, Tenerife.

Brito, A., Falcón, J.M. \& Herrera, R. (2005) About the recent tropicalisation of the littoral ichthyofauna of the Canary Islands and its relationship with environmental changes and human activities. Vieraea, 33, 515-525.

Bromham, L. \& Penny, D. (2003) The modern molecular clock. Nature Genetics, 4, 216-224.

Brooks, D.R. (2004) Reticulations in historical biogeography: the triumph of time over space in evolution. Frontiers in biogeography (ed. by M. Lomolino and L. Heaney), pp. 125144. Sinauer Press, Sunderland, MA.

Budd, A.F. (2000) Diversity and extinction in the Cenozoic history of Caribbean reefs. Coral Reefs, 19, 25-35.

Burgess, G.H., Smith, S.H. \& Lane, E.D. (1994) Fishes of the Cayman Islands. The Cayman Islands: natural history and biogeography (ed. by M.A. Brunt and J.E. Davies), pp. 199228. Kluwer Academic Publishers, Dordrecht.

Carlin, J.L., Robertson, D.R. \& Bowen, B.W. (2003) Ancient divergences and recent connections in two tropical Atlantic reef fishes: Epinephelus adscensionis and Rypticus saponaceous (Percoidei: Serranidae). Marine Biology, 143, 10571069.

Carnevale, G. (2006) Morphology and biology of the Miocene butterflyfish Chaetodon ficheuri (Teleostei: Chaetodontidae). Zoological Journal of the Linnean Society, 146, 251-267.

Carvalho-Filho, A. (1999) Peixes: Costa Brasileira, 3rd edn. Melro, São Paulo.

Casey, S.P., Hall, H.J., Stanley, H.F. \& Vincent, A.C.J. (2004) The origin and evolution of seahorses (genus Hippocampus): a phylogenetic study using the cytochrome b gene of mitochondrial DNA. Molecular Phylogenetics and Evolution, 30, 261-272.

Cervigón, F. (1982) Los Peces Marinos de Venezuela. Fundacion Cientifica Los Roques, Caracas, Venezuela.

Claro, R. \& Parenti, L.R. (2001) The marine ichthyofauna of Cuba. Ecology of the marine fishes of Cuba (ed. by R. Claro, K.C. Lindeman and L.A. Parenti), pp. 21-57. Smithsonian Institution Press, Washington, DC.

Coates, A.G. \& Obando, J.A. (1996) The geologic evolution of the Central American isthmus. Evolution and environments in tropical America (ed. by J.B.C. Jackson, A.F. Budd and A.G. Coates), pp. 21-56. University of Chicago Press, Chicago.

Costagliola, D., Robertson, D.R., Guidetti, P., Stefanni, S., Wirtz, P., Heiser, J.B. \& Bernardi, G. (2004) Evolution of coral reef fish Thalassoma spp. (Labridae). 2. Evolution of the eastern Atlantic species. Marine Biology, 144, 377-383.

Cousseau, M.B. \& Perrota, R.G. (2004) Peces Marinos de Argentina: Biologia, Distribución, Pesca. INIDEP. Instituto
Nacional de Investigación y Desarrollo Pesquero, Mar del Plata, Argentina.

Craig, M.T. \& Hastings, P.A. (2007) A molecular phylogeny of the groupers of the subfamily Epinephelinae (Serranidae) with a revised classification of the Epinephelini. Ichthyological Research, 54, 1-17.

Craig, M.T., Hastings, P.A. \& Pondella, D.J. (2004) Speciation in the Central American Seaway: the importance of taxon sampling in the identification of trans-isthmian geminate pairs. Journal of Biogeography, 31, 1085-1091.

Craig, M.T., Bartsch, P., Wirtz, P. \& Heemstra, P.C. (2006) Redescription and validation of Alphestes afer (Bloch 1793) as an amphi-Atlantic grouper species (Perciformes: Serranidae). Cybium, 30, 327-331.

Cunha, R.L., Castilho, R., Rüber, L. \& Zardoya, R. (2005) Patterns of cladogenesis in the venomous marine gastropod genus Conus from the Cape Verde Islands. Systematic Biology, 54, 634-650.

Dennis, G.D., Smith-Vaniz, W.F., Colin, P.L., Hensley, D.A. \& McGehee, M.A. (2005) Shore fishes known from islands of the Mona Passage, Greater Antilles with comments on their zoogeography. Caribbean Journal of Science, 41, 716-743.

Díaz de Astarloa, J.M., Figueroa, D.E. \& Reta, R. (2003) First documented occurrence of the starry toadfish Arothron firmamentum (Teleostei: Tetraodontidae) in the south-west Atlantic. Journal of the Marine Biological Association of the United Kingdom, 83, 879-880.

Domingues, V.S., Bucciarelli, G., Almada, V.C. \& Bernardi, G. (2005) Historical colonization and demography of the Mediterranean damselfish, Chromis chromis. Molecular Ecology, 14, 4051-4063.

Domingues, V.S., Santos, R.S., Brito, A. \& Almada, V. (2006) Historical population dynamics and demography of the eastern Atlantic pomacentrid Chromis limbata (Valenciennes, 1833). Molecular Phylogenetics and Evolution, 40, 139-147.

Domingues, V.S., Almada, V.C., Santos, R.S., Brito, A. \& Bernardi, G. (2007) Phylogeography and evolution of the triplefin Tripterygion delaisi (Pisces, Blennioidei). Marine Biology, 150, 509-519.

Duda, T.F.J. \& Rolán, E. (2005) Explosive radiation of Cape Verde Conus, a marine species flock. Molecular Ecology, 14, 267-272.

Dutra, G.F., Allen, G.R., Werner, T. \& McKenna, S.A. (eds) (2005) A rapid marine biodiversity assessment of the $A b$ rolhos Bank, Bahia, Brazil. RAP Bulletin of Biological Assessment, 38. Conservation International, Washington, DC.

Edmunds, M. (1977) Larval development, oceanic currents, and origins of the Opisthobranch fauna of Ghana. Journal of Molluscan Studies, 43, 301-308.

Edwards, A.J. (1987) Zoogeography of Red Sea fishes. Key environments: Red Sea (ed. by A.J. Edwards and S.M. Head), pp. 279-286. Pergamon Press, Oxford.

Edwards, A.J. (1990) Fish and fisheries of Saint Helena Island. Centre for Tropical Coastal Management Studies, University of Newcastle upon Tyne, UK. 
Edwards, A.J. \& Glass, C.W. (1987a) The fishes of St Helena Island, South Atlantic Ocean. I. The shore fishes. Journal of Natural History, 21, 617-686.

Edwards, A.J. \& Glass, C.W. (1987b) The fishes of St Helena Island, South Atlantic Ocean. II. The pelagic fishes. Journal of Natural History, 21, 1367-1394.

Edwards, A.J. \& Lubbock, R. (1983) Marine zoogeography of St. Paul's Rocks. Journal of Biogeography, 10, 65-72.

Edwards, A.J., Gill, A.C. \& Abohweyere, P.O. (2003) A revision of F. R. Irvine's Ghanaian marine fishes in the collections of The Natural History Museum, London. Journal of Natural History, 37, 2213-2267.

Ekman, S. (1953) Zoogeography of the sea. Sigwick and Jackson, London.

Falcón, J.M., Brito, A. \& González, G. (2002) Peces de la laguna de Khnifiss (Sáhara, NW de África) y de los sectores costeros próximos. Revista de la Academia Canaria de Ciencias, 14, $139-152$.

Feitoza, B.M. (2001) Composição e estrutura da comunidade de peixes recifais da Risca do Zumbi, Rio Grande do Norte. MSc Thesis. Universidade Federal da Paraíba, João Pessoa, Brazil.

Feitoza, B.M., Rocha, L.A., Luiz, O.J., Jr, Floeter, S.R. \& Gasparini, J.L. (2003) Reef fishes of St. Paul's Rocks: new records and notes on biology and zoogeography. Aqua Journal of Ichthyology and Aquatic Biology, 7, 61-82.

Feitoza, B.M., Rosa, R.S. \& Rocha, L.A. (2005) Ecology and zoogeography of deep reef fishes in northeastern Brazil. Bulletin of Marine Science, 76, 725-742.

Felsenstein, J. (2004) Inferring phylogenies. Sinauer Associates, Sunderland, MA.

Fessler, J.L. \& Westneat, M.W. (2007) Molecular phylogenetics of the butterflyfishes (Chaetodontidae): Taxonomy and biogeography of a global coral reef fish family. Molecular Phylogenetics and Evolution, doi:10.1016/j.ympev.2007. 05.018

Floeter, S.R. \& Gasparini, J.L. (2000) The southwestern Atlantic reef fish fauna: composition and zoogeographic patterns. Journal of Fish Biology, 56, 1099-1114.

Floeter, S.R., Guimarães, R.Z.P., Rocha, L.A., Ferreira, C.E.L., Rangel, C.A. \& Gasparini, J.L. (2001) Geographic variation in reef-fish assemblages along the Brazilian coast. Global Ecology and Biogeography, 10, 423-433.

Floeter, S.R., Krohling, W., Gasparini, J.L., Ferreira, C.E.L. \& Zalmon, I. (2007) Reef fish community structure on coastal islands of southeastern Brazil: the influence of exposure and benthic cover. Environmental Biology of Fishes, 78, 147160.

Galbo, A.M.L., Carpenter, K.E. \& Reed, D.L. (2002) Evolution of trophic types in emperor fishes (Lethrinus, Lethrinidae, Percoidei) based on cytochrome b gene sequence variation. Journal of Molecular Evolution, 54, 754-762.

Gasparini, J.L. \& Floeter, S.R. (2001) The shore fishes of Trindade Island, southwestern Atlantic. Journal of Natural History, 35, 1639-1656.

Gasparini, J.L., Floeter, S.R. \& Joyeux, J.C. (2003) Sparisoma tuiupiranga, a new species of parrotfish (Perciformes:
Labroidae: Scaridae) from Brazil, with comments on the evolution of the genus. Zootaxa, 384, 1-14.

Gilbert, C.R. (1972) Characteristics of the western Atlantic reef-fish fauna. Quarterly Journal of Florida Academy of Sciences, 35, 130-144.

Gomon, M.F. (1997) Relationships of fishes of the labrid tribe Hypsigenyini. Bulletin of Marine Science, 60, 789-871.

Gonçalves, E.J., Almada, V.C., Almeida, A.J. \& Oliveira, R.F. (1993) On the occurrence of Parablennius sanguinolentus (Pisces: Blenniidae) on the Portuguese coast. Journal of the Marine Biological Association of the United Kingdom, 73, 465-467.

Gonçalves, E.J., Beldade, R. \& Henriques, M. (2005) Opeatogenys gracilis (Pisces: Gobiesocidae): an overlooked species or another 'Mediterranean endemism' found in Atlantic waters? Journal of Fish Biology, 67, 481-489.

Guimarães, R.Z.P. (1999) Revision, phylogeny and comments on biogeography of soapfishes of the genus Rypticus (Teleostei: Serranidae). Bulletin of Marine Science, 65, 337-379.

Hadley-Hansen, P.E. (1986) Revision of the tripterygiid fish genus Helcogramma, including descriptions of four new species. Bulletin of Marine Science, 38, 313-354.

Hastings, P.A. (2000) Biogeography of the tropical eastern pacific: distribution and phylogeny of chaenopsid fishes. Zoological Journal of the Linnean Society, 128, 319-335.

Heemstra, P.C. \& Heemstra, E.(2004) Coastal fishes of Southern Africa. NISC-SAIAB, Grahamstown, South Africa.

Heiser, J.B., Moura, R.L. \& Robertson, D.R. (2000) Two new species of creole wrasse (Labridae: Clepticus) from opposite sides of the Atlantic. Aqua Journal of Ichthyology and Aquatic Biology, 4, 67-76.

Hoorn, C., Guerrero, J., Sarmiento, G.A. \& Lorente, M.A. (1995) Andean tectonics as a cause for changing drainage patterns in Miocene northern South America. Geology, 23, 237-240.

Hostim-Silva, M., Andrade, A.B., Machado, L.F., Gerhardinger, L.C., Daros, F.A., Barreiros, J.P. \& Godoy, E.A.S. (2006) Peixes de Costão Rochoso de Santa Catarina: I. Arvoredo. Editora da Universidade do Vale do Itajaí, Itajaí, Brazil.

Hureau, J.-C. (1998) Fishes of the North-Eastern Atlantic and the Mediterranean: Mac Version (World Biodiversity Database CD-ROM Series). UNESCO, Paris.

Irigoyen, A.J., Galván, D.E. \& Venerus, L.A. (2005) Occurrence of dusky grouper Epinephelus marginatus (Lowe, 1834) in gulfs of northern Patagonia, Argentina. Journal of Fish Biology, 67, 1741-1745.

Jennings, G. (2000) Mediterranean Fishes. A modern taxonomic checklist. Calypso Publications, London. http://www.calypso.org.uk/MedFish2000.pdf.

Johnson, K.G., Todd, J.A. \& Jackson, J.B.C. (2007) Coral reef development drives molluscan diversity increase at local and regional scales in the late Neogene and Quaternary of the southwestern Caribbean. Paleobiology, 33, 24-52.

Joyeux, J.C., Floeter, S.R., Ferreira, C.E.L. \& Gasparini, J.L. (2001) Biogeography of tropical reef fish: the South Atlantic puzzle. Journal of Biogeography, 28, 831-841. 
Kaneps, A.G. (1979) Gulf Stream: velocity fluctuations during the late Cenozoic. Science, 204, 297-301.

Klassen, G.J. (1995) Phylogeny and biogeography of the Ostraciinae (Tetraodontiformes: Ostraciidae). Bulletin of Marine Science, 57, 393-441.

Knowlton, N. \& Weigt, L.A. (1998) New dates and new rates for divergence across the Isthmus of Panama. Proceeding of the Royal Society B: Biological Sciences, 265, 2257-2263.

Leis, J.M. (1991) The pelagic stage of reef fishes: the larval biology of coral reef fishes. The ecology of fishes on coral reefs (ed. by P.F. Sale), pp. 183-230. Academic Press, San Diego.

Lima, D., Freitas, J.E.P., Araujo, M.E. \& Sole-Cava, A.M. (2005) Genetic detection of cryptic species in the frillfin goby Bathygobius soporator. Journal of Experimental Marine Biology and Ecology, 320, 211-223.

Lubbock, R. (1980) The shore fishes of Ascension Island. Journal of Fish Biology, 17, 283-303.

Lubbock, R. \& Edwards, A. (1981) The fishes of Saint Paul's Rocks. Journal of Fish Biology, 18, 135-157.

Luiz, O.J., Jr, Floeter, S.R., Gasparini, J.L., Ferreira, C.E.L. \& Wirtz, P. (2004) The occurrence of the African surgeonfish Acanthurus monroviae (Perciformes: Acanthuridae) in the southwestern Atlantic, with comments on other eastern Atlantic reef fishes occurring in Brazil. Journal of Fish Bio$\log y, 65,1173-1179$.

Marlow, J.R., Lange, C.B., Wefer, G. \& Rosell-Mele, A. (2000) Upwelling intensification as part of the Pliocene-Pleistocene climate transition. Science, 290, 2288-2291.

Menezes, N.A., Buckup, P.A., Figueiredo, J.L. \& Moura, R.L. (eds) (2003) Catálogo das Espécies de Peixes Marinhos do Brasil. Museu de Zoologia da Universidade de São Paulo, São Paulo.

Menezes, G.M., Tariche, O., Pinho, M.R., Duarte, P.N., Fernandes, A. \& Aboim, N.A. (2004) Annotated list of fishes caught by the R/V Arquipélago off the Cape Verde Archipelago. Arquipélago Life and Marine Sciences, 21 A, 57-71.

Menni, R.C., Ringuelet, R.A. \& Aramburu, R.H. (1984) Peces Marinos de la Argentina y Uruguay. Catálogo crítico ilustrado. Claves para identificación de familias, géneros y especies. Nombres vulgares. Glossario. Editorial Hemisferio Sur, Buenos Aires.

Meyer, C.P. (2003) Molecular systematics of cowries (Gastropoda: Cypraeidae) and diversification patterns in the tropics. Biological Journal of the Linnean Society, 79, 401-459.

Moura, R.L. \& Sazima, I. (2003) Species richness and endemism levels of the Brazilian reef fish fauna. Proceedings of the 9th International Coral Reef Symposium, 9, 956-959.

Muss, A., Robertson, D.R., Stepien, C.A., Wirtz, P. \& Bowen, B.W. (2001) Phylogeography of Ophioblennius: the role of ocean currents and geography in reef fish evolution. Evolution, 55, 561-572.

Oliver, P.G. \& von Cosel, R. (1992) Taxonomy of tropical west African Bivalves. IV. Arcidae. Bulletin Muséum National d'Histoire Naturelle Paris, 14, 293-381.

Orrell, T.M., Carpenter, K.E., Musick, J.A. \& Graves, J.E. (2002) Phylogenetic and biogeographic analysis of the
Sparidae (Perciformes: Percoidei) from cytochrome b sequences. Copeia, 2002, 618-631.

Paulay, G. (1997) Diversity and distribution of reef organisms. Life and death of coral reefs (ed. by C. Birkeland), pp. 298353. Chapman \& Hall, New York.

Paulay, G. \& Meyer, C.P. (2002) Diversification in the tropical Pacific: comparisons between marine and terrestrial systems and the importance of founder speciation. Integrative and Comparative Biology, 42, 922-934.

Peeters, F.J.C., Acheson, R., Brummer, G.J.A., de Ruijter, W.P.M., Schneider, R.R., Ganssen, G.M., Ufkes, E. \& Kroon, D. (2004) Vigorous exchange between the Indian and Atlantic oceans at the end of the past five glacial periods. Nature, 430, 661-665.

Pérez-Ruzafa, A., Marcos, C. \& Bacallado, J.J. (2005) Biodiversidad marina en archipiélagos e islas: patrones de riqueza específica y afinidades faunísticas. Vieraea, 33, 455475.

Pittman, W.C., III, Cande, S., LaBrecque, J. \& Pindell, J. (1993) Fragmentation of Gondwana: the separation of Africa from South America. Biological relationships between Africa and South America (ed. by P. Goldblatt), pp. 15-34. Yale University Press, New Haven.

Pulquério, M.J.F. \& Nichols, R.A. (2007) Dates from the molecular clock: how wrong can we be? Trends in Ecology and Evolution, 22, 180-184.

Quattrini, A.M., Ross, S.W., Sulak, K.J., Necaise, A.M., Casazza, T.L. \& Dennis, G.D. (2004) Marine fishes new to continental United States waters, North Carolina, and the Gulf of Mexico. Southeastern Naturalist, 3, 155-172.

Queiroz, A. (2005) The resurrection of oceanic dispersal in historical biogeography. Trends in Ecology and Evolution, 20, $68-73$.

Quenouille, B., Bermingham, E. \& Planes, S. (2004) Molecular systematics of the damselfishes (Teleostei: Pomacentridae): Bayesian phylogenetic analyses of mitochondrial and nuclear DNA sequences. Molecular Phylogenetics and Evolution, 31, 66-88.

Quéro, J.C., Hureau, J.C., Karrer, C., Post, A. \& Saldanha, L.(eds.) (1990) Check-list of the fishes of the eastern tropical Atlantic (CLOFETA), 3 volumes. JNICT, Lisbon; SEI, Paris; UNESCO, Paris.

Randall, J.E. (1996) Caribbean reef fishes, 3rd edn. TFH, Neptune City, NJ.

Reiner, F. (1996) Catálogo dos Peixes do Arquipélago de Cabo Verde. Publicações Avulsas do IPIMAR, 2, Lisboa.

Reiner, F. (2001) Peixes da Guiné-Bissau. Centro Português de Estudo dos Mamíferos Marinhos, Lisboa.

Robertson, D.R. (1998) Do coral-reef fish faunas have a distinctive taxonomic structure? Coral Reefs, 17, 179-186.

Robertson, D.R., Grove, J.S. \& McCosker, J.E. (2004) Tropical transpacific shore fishes. Pacific Science, 58, 507-565.

Robertson, D.R., Karg, F., Moura, R.L., Victor, B.C. \& Bernardi, G. (2006) Mechanisms of speciation and faunal enrichment in Atlantic parrotfishes. Molecular Phylogenetics and Evolution, 40, 795-807. 
Rocha, L.A. (2003) Patterns of distribution and processes of speciation in Brazilian reef fishes. Journal of Biogeography, 30, 1161-1171.

Rocha, L.A. (2004) Mitochondrial DNA and color pattern variation in three Western Atlantic Halichoeres (Labridae), with the revalidation of two species. Copeia, 2004, 770782.

Rocha, L.A. \& Rosa, I.L. (1999) New species of Haemulon (Teleostei: Haemulidae) from the NE Brazilian Coast. Copeia, 1999, 447-452.

Rocha, L.A. \& Rosa, I.L. (2001) Baseline assessment of reef fish assemblages of Parcel Manuel Luiz Marine State Park, Maranhão, north-east Brazil. Journal of Fish Biology, 58, 985-998.

Rocha, L.A., Rosa, I.L. \& Rosa, R.S. (1998) Peixes recifais da costa da Paraíba, Brasil. Revista brasileira de Zoologia, 15, 553-566.

Rocha, L.A., Bass, A.L., Robertson, D.R. \& Bowen, B.W. (2002) Adult habitat preferences, larval dispersal, and the comparative phylogeography of three Atlantic surgeonfishes (Teleostei: Acanthuridae). Molecular Ecology, 11, 243252.

Rocha, L.A., Robertson, D.R., Rocha, C.R., Van Tassell, J.L., Craig, M.T. \& Bowen, B.W. (2005a) Recent invasion of the tropical Atlantic by an Indo-Pacific coral reef fish. Molecular Ecology, 14, 3921-3928.

Rocha, L.A., Robertson, D.R., Roman, J. \& Bowen, B.W. (2005b) Ecological speciation in tropical reef fishes. Proceedings of the Royal Society B: Biological Sciences, 272, 573-579.

Rosa, R.S. \& Moura, R.L. (1997) Visual assessment of reef fish community structure in the Atol das Rocas Biological Reserve, off northeastern Brazil. Proceedings of the 8th International Coral Reef Symposium, 1, 983-986.

Rosenblatt, R.H. (1967) The zoogeographic relationships of the marine shore fishes of tropical America. Studies in Tropical Oceanography, 5, 579-592.

Sampaio, C.L.S., Carvalho-Filho, A., Feitoza, B.M., Ferreira, C.E.L., Floeter, S.R., Gasparini, J.L., Rocha, L.A. \& Sazima, I. (2006) Peixes recifais endêmicos e ameaçados das Ilhas Oceânicas Brasileiras e do Complexo Recifal de Abrolhos. Ilhas Oceânicas Brasileiras - da Pesquisa ao Manejo (ed. by R.J.V. Alves and J.W. de Alencar Castro), pp. 217-234. MMA, Brasília.

Santos, R.S., Porteiro, F.A. \& Barreiros, J.P. (1997) Marine fishes of the Azores. Annotated checklist and bibliography. Arquipélago, Life and Marine Sciences, Bulletin of the University of the Azores, Supplement 1.

Sazima, I., Gasparini, J.L. \& Moura, R.L. (1998) Gramma brasiliensis, a new basslet from the western South Atlantic (Perciformes: Grammatidae). Aqua Journal of Ichthyology and Aquatic Biology, 3, 39-43.

Schmitter-Soto, J.J., Vásquez-Yeomans, L., Aguilar-Perera, A., Curiel-Mondragón, C. \& Caballero-Vázquez, J.A. (2000) Lista de peces marinos del Caribe mexicano. Anales del Instituto de Biología Universidad Autónoma de México. Serie Zoología, 71, 143-177.
Shannon, L.V. (1985) The Benguela ecosystem. Part I. Evolution of the Benguela physical features and processes. Oceanography and Marine Biology Annual Reviews, 23, 105-182.

Shulman, M.J. \& Bermingham, E. (1995) Early life histories, ocean currents, and population genetics of Caribbean reef fishes. Evolution 49, 897-910.

Smith, C.L. (1997) Tropical marine fishes of the Caribbean, the Gulf of Mexico, Florida, the Bahamas, and Bermuda. Alfred A. Knopf, Inc., New York.

Smith, M.M. \& Heemstra, P.C. (1995) Smiths' sea fishes. Southern Book Publishers, Johannesburg.

Smith, M.L., Carpenter, K.E. \& Waller, R.W. (2002) An introduction to the oceanography, geology, biogeography, and fisheries of the tropical and subtropical western central Atlantic. The living marine resources of the western central Atlantic (ed. by K.E. Carpenter), pp. 1-23. FAO species identification guide for fishery purposes and American Society of Ichthyologists and Herpetologists Special Publication No. 5, Vol. 1, FAO, Rome.

Smith, C.L., Tyler, J.C., Davis, W.P., Jones, R.S., Smith, D.G. \& Baldwin, C.C. (2003) Fishes of the Pelican Cays, Belize. Atoll Research Bulletin, 497. National Museum of Natural History, Smithsonian Institution, Washington, DC.

Smith-Vaniz, W.F., Collette, B.B. \& Luckhurst, B.E.(1999) Fishes of Bermuda: history, zoogeography, annotated checklist, and identification keys. ASIH, Special Publication Number 4, Lawrence, KS.

Smith-Vaniz, W.F., Jelks, H.L. \& Rocha, L.A. (2006) Relevance of cryptic fishes in biodiversity assessments: a case study at Buck Island Reef National Monument, St. Croix. Bulletin of Marine Science, 79, 17-48.

Steininger, F.F. \& Rögl, F. (1984) Paleography and palinspastic reconstruction of the Neogene of the Mediterranean and Paratethys. The geological evolution of the eastern Mediterranean (ed. by J.E. Dixon and A.H.F. Robertson), pp. 659668. Blackwell Scientific Publications, Oxford.

Stramma, L. \& Schott, F. (1999) The mean flow field of the tropical Atlantic Ocean. Deep-Sea Research II, 46, 279-303.

Streelman, J.T., Alfaro, M., Westneat, M.W., Bellwood, D.R. \& Karl, S.A. (2002) Evolutionary history of the parrotfishes: biogeography, ecomorphology, and comparative diversity. Evolution, 56, 961-971.

Summerer, M., Hanel, R. \& Sturmbauer, C. (2001) Mitochondrial phylogeny and biogeographic affinities of sea breans of the genus Diplodus (Sparidae). Journal of Fish Biology, 59, 1638-1652.

Swofford, D.L. (2002) PAUP*: Phylogenetic Analyses using Parsimony (*and Other Methods), Version 4. Sinauer Associates, Sutherland, MA.

Taylor, M.S. \& Hellberg, M.E. (2005) Marine radiations at small geographic scales: speciation in neotropical reef gobies (Elacatinus). Evolution, 59, 374-385.

Taylor, M.S. \& Hellberg, M.E. (2006) Comparative phylogeography of a genus of coral reef fishes: biogeographical and genetical concordance in the Caribbean. Molecular Ecology, 15, 695-707. 
Tyler, J.C. (1997) The Miocene fish Marosichthys, a putative tetraodontiform, actually a perciform surgeon fish (Acanthuridae) related to recent Naso. Beaufortia, 47, 1-10.

Vermeij, G.J. (1978) Biogeography and adaptation: patterns of marine life. Harvard University Press, Cambridge, MA.

Vermeij, G.J. (1996) Marine biological diversity: muricid gastropods as a case study. Evolutionary paleobiology (ed. by D. Jablonski, D.H. Erwin and J.H. Lipps), pp. 355-375. University of Chicago Press, Chicago.

Vermeij, G.J. (2001) Community assembly in the sea: geological history of the living shore biota. Marine community ecology (ed. by M.D. Bertness, S.D. Gaines and M.E. Hay) pp. 39-60. Sinauer Associates, Sunderland, MA.

Vermeij, G.J. (2005) One-way traffic in the western Atlantic: causes and consequences of Miocene to early Pleistocene molluscan invasions in Florida and the Caribbean. Paleobio$\log y$, 31, 624-642.

Vermeij, G.J. \& Rosenberg, G. (1993) Giving and receiving the tropical Atlantic as donor and recipient for invading species. American Malacological Bulletin, 10, 181-194.

Vermeij, G.J. \& Snyder, M.A. (2003) The fasciolariid gastropod genus Benimakia: New species and a discussion of IndoPacific genera in Brazil. Proceedings of the Academy of Natural Sciences of Philadelphia, 153, 15-22.

Veron, J.E.N. (1995) Corals in space and time: the biogeography and evolution of the Scleractinia. University of New South Wales Press, Sydney.

Victor, B.C. (1991) Settlement strategies and biogeography of reef fishes. The ecology of fishes on coral reefs (ed. by P.F. Sale), pp. 231-260. Academic Press, San Diego.

Wilk, K., Wilk, K. \& Greenfield, D.W. (2005) First record of the Eastern Atlantic Squirelfish Sargocentron hastatum (Holocentridae) from the Western Atlantic Ocean. Proceedings of the California Academy of Sciences, 56, 86-87.

Williams, S.T. \& Reid, D.G. (2004) Speciation and diversity on tropical rocky shores: a global phylogeny of snails of the genus Echinolittorina. Evolution, 58, 2227-2251.
Wirtz, P. (2001) Madeira, marine life. Francisco Ribeiro \& Filhos LDA, Funchal, Portugal.

Wirtz, P., Ferreira, C.E.L., Floeter, S.R., Fricke, R., Gasparini, J.L., Iwamoto, T., Rocha, L.A., Sampaio, C.L. \& Schliewen, U. (2007) Coastal fishes of São Tomé and Príncipe - an update. Zootaxa, 1523, 1-48.

Wonham, M.J., Carlton, J.T., Ruiz, G.M. \& Smith, L.D. (2000) Fish and ships: relating dispersal frequency and success in biological invasions. Marine Biology, 136, 1111-1121.

\section{SUPPLEMENTARY MATERIAL}

The following supplementary material is available for this article online:

Table S1 Atlantic reef fish data base.

Table S2 Sister-species table and references.

This material is available as part of the online article from: http://www.blackwell-synergy.com/doi/abs/10.1111/j. 1365-2699.2007.01790.x

Please note: Blackwell Publishing is not responsible for the content or functionality of any supplementary materials supplied by the authors. Any queries (other than missing material) should be directed to the corresponding author for the article.

BIOSKETCH

Sergio R. Floeter has held a position as professor in vertebrate zoology at the Universidade Federal de Santa Catarina in southern Brazil since 2006. His main research interests are reef fish macroecology, biogeography, evolution, and conservation. He also plays the guitar.

Editor: David Bellwood 